\title{
Neuronal Diversity in GABAergic Long-Range Projections from the Hippocampus
}

\author{
Shozo Jinno, ${ }^{1}$ Thomas Klausberger, ${ }^{1,2}$ Laszlo F. Marton, ${ }^{1,3}$ Yannis Dalezios,,${ }^{1,4,5}$ J. David B. Roberts, ${ }^{1}$ Pablo Fuentealba, ${ }^{1}$ \\ Eric A. Bushong, ${ }^{1}$ Darrell Henze, ${ }^{6}$ György Buzsáki, ${ }^{6}$ and Peter Somogyi ${ }^{1}$ \\ ${ }^{1}$ Medical Research Council Anatomical Neuropharmacology Unit, Department of Pharmacology, Oxford University, Oxford OX1 3TH, United Kingdom, \\ ${ }^{2}$ Center for Brain Research, Medical University of Vienna, 1090 Vienna, Austria, ${ }^{3}$ Neural Systems Research Group, Faculty of Engineering, Sapientia- \\ Hungarian University of Transylvania, R0-540485 Targu Mures, Romania, ${ }^{4}$ Faculty of Medicine, University of Crete, 71003 Heraklion, Greece, ${ }^{5}$ Institute of \\ Applied and Computational Mathematics, Foundation for Research and Technology-Hellas, GR-711 10 Heraklion, Greece, and ${ }^{6}$ Center for Molecular and \\ Behavioral Neuroscience, Rutgers, The State University of New Jersey, Newark, New Jersey 07102-1811
}

The formation and recall of sensory, motor, and cognitive representations require coordinated fast communication among multiple cortical areas. Interareal projections are mainly mediated by glutamatergic pyramidal cell projections; only few long-range GABAergic connections have been reported. Using in vivo recording and labeling of single cells and retrograde axonal tracing, we demonstrate novel long-range GABAergic projection neurons in the rat hippocampus: (1) somatostatin- and predominantly mGluR $1 \alpha$-positive neurons in stratum oriens project to the subiculum, other cortical areas, and the medial septum; (2) neurons in stratum oriens, including somatostatin-negative ones; and (3) trilaminar cells project to the subiculum and/or other cortical areas but not the septum. These three populations strongly increase their firing during sharp wave-associated ripple oscillations, communicating this network state to the septotemporal system. Finally, a large population of somatostatin-negative GABAergic cells in stratum radiatum project to the molecular layers of the subiculum, presubiculum, retrosplenial cortex, and indusium griseum and fire rhythmically at high rates during theta oscillations but do not increase their firing during ripples. The GABAergic projection axons have a larger diameter and thicker myelin sheet than those of CA1 pyramidal cells. Therefore, rhythmic IPSCs are likely to precede the arrival of excitation in cortical areas (e.g., subiculum) that receive both glutamatergic and GABAergic projections from the $\mathrm{CA} 1$ area. 0 ther areas, including the retrosplenial cortex, receive only rhythmic GABAergic CA1 input. We conclude that direct GABAergic projections from the hippocampus to other cortical areas and the septum contribute to coordinating oscillatory timing across structures.

Key words: cerebral cortex; inhibition; interneuron; oscillation; rhythm; axon

\section{Introduction}

Coordinated fast communication among multiple areas of the cerebral cortex is thought to be mediated by glutamatergic pyramidal cell projections (Ramon y Cajal, 1911; Amaral and Witter,

\footnotetext{
Received April 23, 2007; revised June 1, 2007; accepted June 11, 2007.

This work was supported by the Medical Research Council, by National Institutes of Health Grant MH54671 (G.B.), and by Specific Target Research Project Grant INTERDEVO (LSHM-CT-2004-005139) in the Framework 6 program of the European Union (P.F., P.S.). T.K. was supported also by Austrian Science Fund Grant P16637. Wethank Drs. Laszlo Acsady, Attila Gulyas, and Norbert Hájos for their constructive comments on a previous version of this paper; Dr. Catherine Bleasdale and Katja Hartwich for some recordings; Dr. Agnes Baude for help with immunocytochemistry; and Dr. Edit Papp and Muhammad J. Iqbal for cell reconstructions. Wai Yee Suen and Klara Peto provided exper histological assistance, and Dr. Jozsef Somogyi helped with confocal microscopy. We are grateful to Drs. K. Baimbridge, A. Buchan, R. Shigemoto, W. Sieghart, and M. Watanabe for the generous gift of antibodies.

Correspondence should be addressed to any of the following: Dr. Shozo Jinno, Department of Anatomy and Neurobiology, Graduate School of Medical Sciences, Kyushu University, Maidashi 3-1-1, Higashi-ku, Fukuoka 8128582, Japan, E-mail: sjnno@med.kyushu-u.ac.jp; Drs. Thomas Klausberger or Peter Somogyi, Medical Research Council Anatomical Neuropharmacology Unit, Department of Pharmacology, Oxford University, Oxford OX13TH, UK, E-mail: thomas.klausberger@pharmacology.oxford.ac.uk or peter.somogyi@pharmacology.oxford.ac.uk.

D. A. Henze's present address: Merck, Department of Neuroscience, 770 Sumneytown Pike, WP44E-200, P.0. Box 4, West Point, PA 19486.

E. A. Bushong's present address: National Center for Microscopy and Imaging Research, University of California, San Diego, La Jolla, CA 92093-0608.

D01:10.1523/JNEUROSCI.1847-07.2007

Copyright $\odot 2007$ Society for Neuroscience $\quad 0270-6474 / 07 / 278790-15 \$ 15.00 / 0$
}

1989; Felleman and Van Essen, 1991; Rockland, 1997), which form the main corticocortical interareal connections. However, it is not clear how highly coherent activity at a precision of milliseconds is achieved over areas covering hundreds of millimeters by richly branched axons with a wide range of conduction velocities. Synchronization of oscillatory network states across different cortical regions has been suggested to serve conceptual grouping, fear conditioning, sensory-motor integration, stimulus selection, and working memory (Uhlhaas and Singer, 2006). The need for efficient synchronization at the optimal frequencies is a prerequisite for normal cortical computation, because its breakdown may contribute to disorders, including epilepsy, schizophrenia, and depression.

The mechanisms underlying long-range coordinated timing of neuronal activity are currently debated. Excitatory principal cells monosynaptically innervate both glutamatergic principal cells and local GABAergic interneurons in each target area (Buzsaki, 1984; Somogyi et al., 1998), and these GABAergic cells are thought to play a key role in the local synchronization of principal cells. Interneurons temporally coordinate principal neuron activity and modify multiple operations in principal cells via cell domain-specific local synaptic innervation (Miles et al., 
1996; Somogyi et al., 1998). Long-range excitatory connections in concert with subcortical inputs from the thalamus, basal forebrain, and brainstem can, in principle, provide a substrate for short-latency synchrony in distant cortical areas. However, longrange GABAergic connections are also well suited to coordinating the timing of activity between brain regions (Buzsaki and Chrobak, 1995).

In a few cases, cortical GABAergic cells send long-range projections to subcortical and other cortical areas particularly in the temporal lobe. For example, hippocampal GABAergic neurons innervate the medial septum (Alonso and Kohler, 1982) and commissural GABAergic cells interconnect the dentate gyri (Ribak et al., 1986; Leranth and Frotscher, 1987). Other interareal connections include the projection from the presubiculum to the entorhinal cortex (van Haeften et al., 1997) and interregional connections of hippocampal fields (Sik et al., 1994, 1995; Ceranik et al., 1997; Losonczy et al., 2002; Gulyas et al., 2003; Ferraguti et al., 2005). Long-range GABAergic projections have also been described in the isocortex (Gonchar et al., 1995; Fabri and Manzoni, 1996, 2004; Jinno and Kosaka, 2004; Tomioka et al., 2005). Nevertheless, long-range GABAergic interactions are absent from most cellular network schemes and models (Buzsaki and Chrobak, 1995), mainly because of prevailing uncertainty about the wiring of cell types forming these pathways and a complete lack of knowledge of their activity.

Here, we recorded the in vivo firing of identified long-range GABAergic neurons during network oscillations and visualized their axonal projections to the medial septum, subiculum, presubiculum, indusium griseum, and/or retrosplenial cortex. Several novel GABAergic cell types and pathways have been found. To reveal how widespread such connections are, we also used retrograde axonal labeling and immunocytochemical characterization of a large population of projecting GABAergic neurons.

\section{Materials and Methods}

Electrophysiological recording and cell labeling in vivo. All procedures involving experimental animals were performed in accordance with the Animals (Scientific Procedures) Act of 1986 and associated procedures. The nine recorded projection neurons were obtained from nine rats. Male Sprague Dawley rats (250-350 g) were anesthetized with urethane $(1.25 \mathrm{~g} / \mathrm{kg}$ body weight), plus supplemental doses of ketamine and xylazine (20 and $2 \mathrm{mg} / \mathrm{kg}$ body weight, respectively) as needed; body temperature was maintained with a heating pad. Neuronal activity was recorded extracellularly with a glass electrode $(18-25 \mathrm{M} \Omega$ ) filled with $1.5 \%$ neurobiotin in $0.5 \mathrm{M} \mathrm{NaCl}$, and the local field potential (LFP) was recorded with the same electrode or a nearby second electrode in the hippocampal CA1 pyramidal cell layer. Single-unit activity (sampling rate, $20 \mathrm{kHz}$ ) and LFP (sampling rate, 800 or $1000 \mathrm{~Hz}$ ) were filtered on-line between 0.8 and $5 \mathrm{kHz}$ and direct current to 220 or $0.3-300 \mathrm{~Hz}$, respectively. Nonpyramidal cells were tentatively identified by the lack of complex spike bursts characteristic of pyramidal cells, by narrow spike width, or sometimes only by a conspicuous firing pattern, such as persistent firing during theta activity. During extracellular recording, care was taken not to get too close to the cell by stepping back if the action potential amplitude increased, because contacting it might change its firing pattern. We tried to record and label all putative nonpyramidal neurons to avoid cell sampling bias for cells with a particular firing pattern only. After extracellular recording, the pipette was advanced to a juxtacellular position, and the recorded neuron was specifically labeled with neurobiotin using current pulses. One cell was recorded intracellularly with a sharp electrode with anesthesia and recording protocols as described previously (Henze et al., 2002). Four to six hours after labeling, the rats were perfused with a fixative containing $4 \%$ paraformaldehyde, $0.05-0.1 \%$ glutaraldehyde, and $15 \% \mathrm{v} / \mathrm{v}$ saturated picric acid in $0.1 \mathrm{~m}$ phosphate buffer (Somogyi and Takagi, 1982). The brains were dissected out and cut transversely into $70-\mu \mathrm{m}$-thick serial sections on a vibratome.
Physiological data analysis. The detection of theta, nontheta/nonsharp wave, and ripple episodes, the beginning $(-1)$, highest amplitude $(0)$, and end (1) of ripple episodes, and the calculation of discharge frequencies of single cells during different brain states was performed as described previously (Klausberger et al., 2003). For gamma oscillations, the local field potential was filtered between 30 and $80 \mathrm{~Hz}$, and only gamma cycles with an amplitude bigger than the mean of all gamma cycles recorded for this cell were considered further to exclude those gamma cycles that might be contaminated by noise. To determine the relationship between single spikes and the phase of theta, gamma, and ripple oscillations, the troughs of the cycles were detected in a filtered signal. Each spike was assigned to a given phase (bin size, $18^{\circ}$ ) between the troughs $\left(0\right.$ and $\left.360^{\circ}\right)$. The phase of spike timing was analyzed using circular statistics. Because the phase of gamma oscillations was often distorted by spikes recorded from the same glass electrode, and the phase of gamma oscillations starts to reverse at the stratum pyramidale/radiatum border, the gamma phase could only be unequivocally evaluated for the three neurons located in stratum oriens.

Tissue processing and immunocytochemical analysis. Sections were processed as described previously (Klausberger et al., 2005). Briefly, in the immunofluorescence experiments, sections were incubated in mixtures of primary antibodies raised in different species (Table S1, available at www.jneurosci.org as supplemental material) for $48 \mathrm{~h}$ at $4^{\circ} \mathrm{C}$. After washing, sections were incubated in a mixture of appropriate secondary antibodies conjugated with 7-amino-4-methylcoumarin-3-acetic acid (Jackson ImmunoResearch, West Grove, PA), Alexa Fluor 488 (Invitrogen, Eugene, OR), indocarbocyanine (Cy3; Jackson ImmunoResearch), and indodicarbocyanine (Cy5; Jackson ImmunoResearch) overnight at $4^{\circ} \mathrm{C}$. They were washed in phosphate buffer, mounted in Vectashield (Vector Laboratories, Burlingame, CA), and examined with a fluorescent microscope (Leica, Wetzlar, Germany). Images were captured through a CCD camera (C4747-95; Hamamatsu Photonics, Hamamatsu, Japan) with an appropriate filter set (Ferraguti et al., 2005) and analyzed using the image analysis software package Openlab 4.0.4 (Improvision, Coventry, UK). Selected sections were also analyzed with a confocal laser-scanning microscope (LSM510; Zeiss, Oberkochen, Germany). Only brightness and contrast were adjusted for the whole frame, and no part of a frame was enhanced or modified in any way. Immunoreactions were performed with all necessary controls, as described previously (Ferraguti et al., 2005). Cells were considered immunonegative for a molecule when fluorescence was undetectable in the tested part of the cell (soma and/or dendrite and/or axon terminal) in an area where similar parts of other unrecorded cells were immunopositive. Method specificity was tested by omitting the primary antibodies in the incubation sequence. To control for a possible cross reactivity between IgGs in double and triple immunolabeling experiments, some sections were processed through the same immunocytochemical sequence, except that only one primary antibody was applied, but the full complement of secondary antibodies was maintained. In addition, the secondary antibodies used were highly preadsorbed to the IgGs of numerous species. Specificities of these antibodies are described in the cited references (Table S1, available at www.jneurosci. org as supplemental material).

Reconstruction of recorded cells and electron microscopy. After the completion of immunoreactions, neurobiotin was visualized with 3-3'diaminobenzidine (Sigma, Dorset, UK) using an ABC kit (Vector Laboratories), and the sections were processed for embedding on glass slides in epoxy resin (Durcupan; Fluka, Buchs, Switzerland) as for electron microscopy. Processes of the neurobiotin-filled cells were traced using a $100 \times$ oil immersion objective, and enough sections were superimposed two-dimensionally to represent the laminar patterns of arborizations. Some sections of the axon of each cell were processed for electron microscopic analysis without the use of detergent. Representative areas of the axonal field in the CA1 area and subiculum were serially sectioned for electron microscopy, and the sections were collected on pioloformcoated single-slot copper grids and analyzed in an electron microscope. In the electron microscopic analysis, all synapses found were photographed, and the nature of the postsynaptic target was determined using published criteria. Briefly, in str. radiatum and oriens, pyramidal cells receive type 1 synapses exclusively on their dendritic spines, whereas 
interneurons receive them mostly on their dendritic shafts and, to a lesser extent, on their spines. Pyramidal cell dendrites are densely spiny, whereas interneuron dendrites only have occasional spines. In addition, pyramidal cell dendrites have frequent electron opaque clumps of dense material of $50-100 \mathrm{~nm}$ in diameter and associated with the endoplasmic reticulum. Such dense bodies have not been identified in interneurons.

The diameters of projection interneuron and CA1 pyramidal axons were measured at a final magnification of $47,000 \times$ in electron micrographs of serial 70-nm-thick sections at two to three levels obtained from one $70-\mu \mathrm{m}$-thick resin-embedded section of the axon. Pyramidal axons were measured in the white matter of the subiculum before they entered the gray matter. Caudally directed interneuron axons were measured either in the white matter of the CA1 area distal to the last intra-CA1 branching (P13c, C25a), in the subicular molecular layer (T80a), in the white matter of the subiculum before any branching (K98e), or in CA1 str. lacunosum-moleculare (T100). The main axon of cell D150 was measured in the CA1 alveus before it divided into two approximately equal collaterals. Because no electron microscopically processed section was available of the branch heading caudally in the white matter of the subiculum, we calculated its approximate diameter, as that resulting in half cross-sectional area of the measured main axon. Because the axons are of irregular shape, at each level, at least two axes were averaged to calculate the diameter and the thickness of myelin sheets was also measured at two sites.

Retrograde and anterograde tracing experiments. Thirty-two adult male Sprague Dawley rats (250-350 g body weight) were used. All animals were anesthetized with a mixture of ketamine ( $70 \mathrm{mg} / \mathrm{kg}$ body weight) and medetomidine $(0.5 \mathrm{mg} / \mathrm{kg}$ body weight). They were mounted in a stereotaxic apparatus and kept under isoflurane anesthesia during surgery. We used Fluorogold (FG; Fluorochrome, Denver, CO) and biotinylated dextran amine (BDA, 10,000; Invitrogen) as retrograde tracers. These tracers were injected unilaterally into either the dorsal subiculum or the medial septum. We confirmed that the labeling patterns obtained with these two tracers were similar, but FG was more sensitive than BDA. Thus, the present data of retrograde labeling were mostly derived from FG injection; only 23 (7\%) hippocampo-subicular cells were characterized from the BDA-injected animals. We also used Phaseolus vulgaris leucoagglutinin (PHA-L; Vector Laboratories) as an anterograde tracer. PHA-L was unilaterally injected to the CA1 area of the dorsal hippocampus of two rats. The coordinates for the injections were as follows: dorsal subiculum, $5.3 \mathrm{~mm}$ posterior to the bregma, $2.0 \mathrm{~mm}$ lateral to the midline, and $3.0 \mathrm{~mm}$ below the pial surface; medial septum, $0.5 \mathrm{~mm}$ anterior to the bregma, $0.0 \mathrm{~mm}$ lateral to the midline, and $6.4 \mathrm{~mm}$ below the pial surface; dorsal hippocampus, $3.6 \mathrm{~mm}$ posterior to the bregma, $1.5 \mathrm{~mm}$ lateral to the midline, and $2.4 \mathrm{~mm}$ below the surface. The tracers FG, $\mathrm{BDA}$, and PHA-L were iontophoretically delivered through a micropipette (GC-120 TF-10; Clark, Reading, UK) with a tip diameter of 15-30 $\mu \mathrm{m}$ under the following conditions: FG, $2.0 \%$ in physiological saline, positive current, $5 \mu \mathrm{A}, 7 \mathrm{~s}$ on, $7 \mathrm{~s}$ off, $10 \mathrm{~min}$; $\mathrm{BDA}, 10 \%$ in physiological saline, positive current, $7 \mu \mathrm{A}, 7 \mathrm{~s}$ on, $7 \mathrm{~s}$ off, $20 \mathrm{~min}$; PHA-L, $2.5 \%$ in sodium PBS, positive current, $4 \mu \mathrm{A}, 7 \mathrm{~s}$ on, $7 \mathrm{~s}$ off, $10 \mathrm{~min}$. After a survival period of $5 \mathrm{~d}$, the animals were deeply anesthetized with a mixture of ketamine and medetomidine at the same doses as above and perfusion fixed with the same fixative described above. The brains were dissected out and cut transversely into $70-\mu \mathrm{m}$-thick serial sections on a vibrating microtome (VT1000S; Leica).

\section{Results}

\section{Terminology}

Functionally related cortical areas caudal to the hippocampal formation such as the subiculum, presubiculum, parasubiculum, and entorhinal cortex have been collectively called retrohippocampal areas (Caviness and Sidman, 1973). For simplicity of reporting, under the term retrohippocampal areas in this study, we include the retrosplenial cortex and indusium griseum, which we show to receive direct GABAergic projection from the hippocampus. Some data in our study, as well as in previous reports (Alonso and Kohler, 1982; Gulyas et al., 2003), were obtained from populations of projection cells labeled by retrograde axonal transport of a tracer from either the medial septum, or the subiculum, which leaves it open whether some cells project to both areas. The terms hippocampo-septal and hippocampo-subicular projection cells, respectively, will be used to denote cells identified by retrograde labeling and/or as a collective term for diverse cell groups targeting one of these areas. Our single-cell labeling experiments revealed that indeed many nonpyramidal cells from the hippocampus project to both areas, and they will be called double-projection cells, a distinct cell group. Other single, identified cells projected only to one or more retrohippocampal areas, which may include the subiculum but not the septum. These could be separated clearly into two groups based on their soma location either in str. radiatum/lacunosum-moleculare or str. oriens, which correlated with differences in both their local axonal arborization within the hippocampus and their firing patterns. These latter cell groups are designated as radiatumretrohippocampal cells and oriens-retrohippocampal cells, respectively, and are considered as distinct cell types or a group of cell types.

\section{Identification of novel nonpyramidal projection neurons recorded in vivo}

Establishing the roles of distinct neuronal types in the network requires information about their electrical activity in vivo, their synaptic connections as revealed by their axons and dendrites, and their molecular composition that supports intercellular signaling. Juxtacellular or intracellular labeling of recorded cells can reveal the complete dendritic arbor and the extent of axons over many millimeters showing projection areas of single cells.

We recorded nine cells identified as nonpyramidal projection neurons (Table 1), in addition to one cell published previously (Ferraguti et al., 2005). The dendrites of all projection nonpyramidal cells were sparsely spiny to a varying extent. Five of them, named here as double-projection neurons (T87c, C25a, D150, $\mathrm{P} 13 \mathrm{c}$, and $\mathrm{C} 11 \mathrm{c})$, sent main axons toward both the retrohippocampal and septal areas (Fig. 1). Of these, four somata were in the CA1 str. oriens, and their thick dendrites extended horizontally. Their local axonal branches, which had mainly en passant boutons in the CAl area, were distributed in str. oriens, radiatum, and to a smaller extent in pyramidale but usually avoided str. lacunosum-moleculare. During the 4-6 h survival period, neurobiotin did not reach the terminals in the septum and only the thick main axons were detected; the retrohippocampal arbors were also partially labeled. The most distant main projection axons of cell D150 were lost because of a processing error. Molecular expression profiles (Table 1) showed that all tested CA1 double-projection cells were positive for somatostatin (SOM) (Fig. $1 G_{2}$ ) and calbindin (CB) (Fig. 1G $G_{3}$ ), and two of four cells tested were positive for metabotropic glutamate receptor $1 \alpha$ $(\mathrm{mGluR} 1 \alpha)$ (Fig. $\left.1 G_{3}\right)$. Parvalbumin (PV), neuropeptide Y (NPY), and muscarinic acetylcholine receptor type 2 (M2R) were detected in one cell each; the synaptic terminals providing input to the somatodendritic domain of T87a, but not those of the other tested cells, were enriched in mGluR7a. One doubleprojection neuron $(\mathrm{C} 11 \mathrm{c})$ was recorded in str. pyramidale of the $\mathrm{CA} 3$ area. The hippocampal axonal arbor of cell $\mathrm{C} 11 \mathrm{c}$ extended to both $\mathrm{CA} 3$ and $\mathrm{CA} 1$ areas, thus providing a CA3 to CA1 GABAergic projection to str. radiatum. This cell was positive for SOM, NPY, and mGluR1 $\alpha$ (Table 1). Tested double-projection cells were immunonegative for calretinin (CR), cholecystokinin (CCK), nitric oxide synthase (NOS) and vasoactive intestinal polypeptide (VIP). 
Table 1. Identification and characterization of in vivo recorded nonpyramidal projection neurons

\begin{tabular}{|c|c|c|c|c|c|c|c|c|c|c|c|c|c|c|c|c|c|}
\hline \multirow[b]{2}{*}{ Cell no. and type } & \multirow[b]{2}{*}{ Soma } & \multirow[b]{2}{*}{ Dendrites } & \multirow[b]{2}{*}{$\begin{array}{l}\text { Hippocampal } \\
\text { axon }\end{array}$} & \multicolumn{2}{|c|}{$\begin{array}{l}\text { Extrahippocampal } \\
\text { targets }\end{array}$} & \multicolumn{12}{|c|}{ Immunocytochemical test } \\
\hline & & & & $\begin{array}{l}\text { Retrohippo- } \\
\text { campal area }\end{array}$ & Septum & PV & CB & CR & SOM & NPY & CCK & VIP & NOS & $M 2 R$ & $\begin{array}{l}\text { mGluR } \\
1 \alpha\end{array}$ & $\begin{array}{l}\text { mGluR 8a } \\
\text { input }\end{array}$ & $\begin{array}{l}\text { mGluR 7a } \\
\text { input }\end{array}$ \\
\hline T87c double-projection & CA1so & CA1so & CA1so, sp, sr & + , b.s.a ${ }^{a}$ & + & - & + & - & + & - & - & - & n.t. & - & + & - & + \\
\hline C25a double-projection & CA1so & CA1so & CA1so, sp, sr & + & + & - & + & - & + & + & n.t. & - & n.t. & - & + & - & - \\
\hline D150 double-projection ${ }^{b}$ & CA1so & CA1so & CA1so, sp, sr & $+^{c}$ & $+^{c}$ & n.t. & n.t. & n.t. & + & - & n.t. & n.t. & n.t. & n.t. & - & n.t. & - \\
\hline P13c double-projection & CA1so & CA1so & CA1so, sp, sr & + & + & + & + & - & + & - & - & n.t. & - & + & - & - & - \\
\hline $\begin{array}{l}\text { T80a oriens- } \\
\text { retrohippocampal }\end{array}$ & CA1so & CA1so & CA1so, sp, sr &,+ b.s. & - & n.t. & + & - & n.t. & n.t. & n.t. & n.t. & n.t. & + & - & - & - \\
\hline $\begin{array}{l}\text { K98c oriens- } \\
\text { retrohippocampal }\end{array}$ & CA1so & CA1so & CA1so, sp, sr & + & - & - & + & n.t. & + & - & n.t. & n.t. & - & n.t. & - & - & - \\
\hline $\begin{array}{l}\text { T85a oriens- } \\
\text { retrohippocampal }^{d}\end{array}$ & CA1so & CA1so & CA1so, sp, sr & + & - & - & - & - & - & - & n.t. & n.t. & n.t. & + & - & + & + \\
\hline $\begin{array}{l}\text { T74b radiatum- } \\
\text { retrohippocampal }\end{array}$ & CA1sr & $\begin{array}{l}\text { CA1sr/ } \\
\text { slm }\end{array}$ & CA1sr, slm &,+ b.s. & - & - & - & - & - & n.t. & - & n.t. & - & n.t. & - & n.t. & n.t. \\
\hline $\begin{array}{l}\text { T100c radiatum- } \\
\text { retrohippocampal }\end{array}$ & $\begin{array}{r}\text { CA1sr/ } \\
\text { slm }\end{array}$ & $\begin{array}{l}\text { CA1sr/ } \\
\text { slm }\end{array}$ & CA1sr, sim & b.s. & - & - & - & - & - & n.t. & - & - & n.t. & n.t. & n.t. & n.t. & - \\
\hline C11c double-projection & CA3sp & $\begin{array}{l}\text { CA3so, } \\
\text { sp, sr }\end{array}$ & $\begin{array}{l}\text { CA1sp, sr } \\
\text { CA3so,sp, sr }\end{array}$ & + & + & - & - & n.t. & + & + & - & n.t. & n.t. & - & + & n.t. & - \\
\hline
\end{tabular}

b.s., Beyond subiculum (the axon projects to cortex beyond the subiculum); n.t., not tested (the reaction was either not performed, or the reaction did not lead to conclusion); mGluR7a, mGluR8a input, these presynaptic receptors are present at high level in the boutons innervating the cell; + , positive; - , not detectable.

${ }^{a}$ The axon was running through the subiculum, but no boutons were found.

${ }^{b}$ D150 was intracellularly recorded with a sharp electrode; the other cells were extracellularly recorded and juxtacellularly labeled.

'Main axon branches were heading towards the septum and subiculum but were lost before their termination could be reached.

${ }^{d}$ T85a has been reported as a trilaminar cell in a previous study (Ferraguti et al., 2005) and included here for comparison.

In addition, we recorded three oriens-retrohippocampal nonpyramidal neurons in str. oriens of the CA1 area (T80a, T85a, K98c), without detectable septal projection (Table 1). Cell T85a has been described previously as a mGluR8-decorated, M2expressing, SOM-negative trilaminar cell (Ferraguti et al., 2005). The dendrites of oriens-retrohippocampal cells extended horizontally in str. oriens and the local axonal arbors, exhibiting en passant boutons in the CA1 area, were distributed in the CA1 str. oriens and radiatum, to a lesser extent in str. pyramidale and only slightly entered str. lacunosum-moleculare (Fig. 2). Long-range axons branched extensively in the subiculum and also innervated the presubiculum (T80a, T85a), but projections to further caudal areas could not be evaluated. Two tested oriensretrohippocampal neurons (Table 1) were immunopositive for $\mathrm{CB}$ (Fig. $2 G_{2}$ ), one for M2R (Fig. $2 G_{3}$ ) and one for SOM. In contrast to double-projection cells, NPY, mGluR $1 \alpha$, and mGluR7a-input were not detected in oriens-retrohippocampal neurons.

Two projection neurons in str. radiatum (T74b, T100c) sending their axons to retrohippocampal areas, but not to the septum, were recorded at the border of str. radiatum and lacunosummoleculare (Fig. 3). Their dendrites extended into str. radiatum and lacunosum-moleculare (Table 1). One cell had very few local axon collaterals in the CA1 area (Fig. 3), but T100c innervated mostly str. lacunosum-moleculare of both the CA1 and CA3 areas, and to a lesser extent str. radiatum having en passant boutons on the axon collaterals. Interestingly, cell T74b also sent a longrange axon in the rostral direction, which entered and branched in the indusium griseum dorsal to the corpus callosum (Fig. 3C) before it was lost because of insufficient neurobiotin labeling. The caudally directed axon of T74b branched extensively in the molecular layer of the subiculum and presubiculum. The main axon of T100c passed through the subiculum and presubiculum without branching. Both cells innervated layer 1 of the retrosplenial cortex (Fig. 3E-G), where they had numerous boutons. These two cells were immunonegative for all tested molecules (Table 1), except glutamate decarboxylase (GAD) (T100c).

The average diameter of caudally projecting interneuron axons was $0.69 \pm 0.10 \mu \mathrm{m}(n=6$ cells $)$, as measured in electron micrographs, and they were all myelinated (mean thickness, $0.19 \pm 0.07 \mu \mathrm{m}$ ) (Figs. $2 \mathrm{H}_{3}, 4 \mathrm{~A}$ ). The diameter of interneuron axons was nearly twice as large as that of pyramidal axons projecting to the subiculum (Fig. $4 B$ ) (mean pyramidal axon diameter, $0.36 \pm 0.06 \mu \mathrm{m} ; n=5$ labeled cells; $p<0.01$, MannWhitney test), and the myelin was three times thicker (mean pyramidal myelin thickness, $0.065 \pm 0.11 \mu \mathrm{m} ; p<0.01$, MannWhitney test). Although it is likely that most, if not all, of the recorded nonpyramidal cells are GABAergic, we could not obtain consistent somatic labeling for GABA or GAD in known GABAergic neurons under our conditions. Therefore, to test the presence of GABAergic axons and terminals of subiculum-bound hippocampal projection, we reacted for the presence of GAD in anterogradely-PHAL-labeled terminals originating from the CA1 area of the dorsal hippocampus (Fig. $4 C-E$ ). As expected, the majority of axonal arbors in the subicular area were GAD negative. Nevertheless, we consistently encountered GAD-positive PHA-L-labeled boutons both in the subiculum and beyond throughout the retrohippocampal regions (data not shown). These results confirm that hippocampal GABAergic neurons send long-range axons to the subiculum and retrohippocampal areas.

\section{In vivo firing patterns of GABAergic projection neurons}

Analyzing the in vivo firing patterns during theta oscillations $(3.9 \pm 0.2 \mathrm{~Hz} ; n=7)$ and sharp wave-associated ripple $(118 \pm 7$ $\mathrm{Hz} ; n=7$ ) episodes indicated two distinct groups of nonpyramidal projection neurons located either in stratum oriens or radiatum (Fig. 5). The four double-projection cells (T87c, C25a, D150, and $\mathrm{P} 13 \mathrm{c}$ ) and two oriens-retrohippocampal neurons (T80a, K98c) and one trilaminar cell (T85a) in the CA1 str. oriens fired 


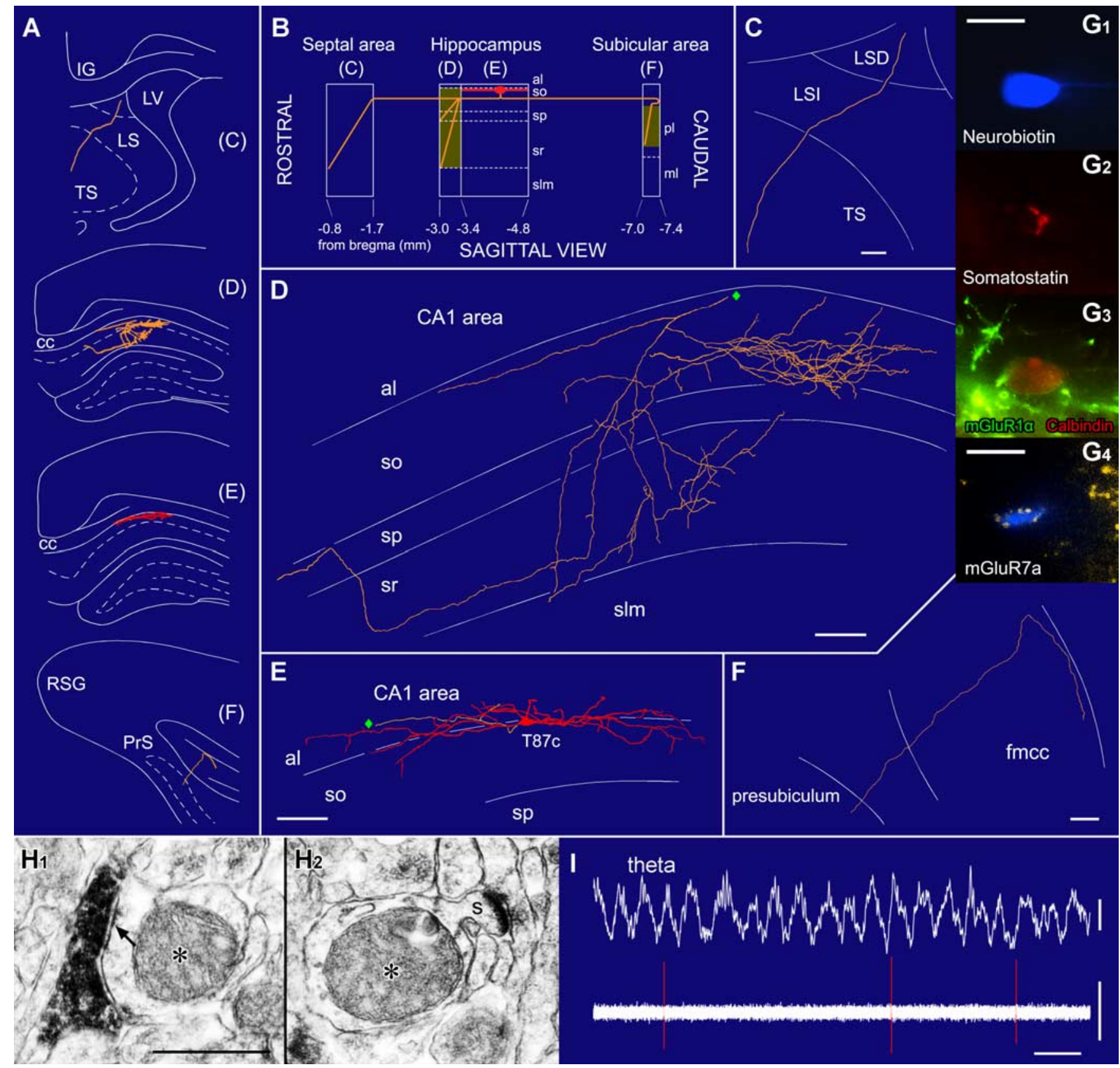

Figure 1. A double-projection neuron (T87c) recorded in vivo innervating both the septal and retrohippocampal areas. $\boldsymbol{A}$, Representation of coronal planes showing the dendritic (red) and axonal (orange) arbors in selected sections indicated as blocks in $\boldsymbol{B}$. $\boldsymbol{B}$, Sagittal plane scheme of the rostrocaudal extent of the dendrites and the axon. The soma and dendrites are in stratum oriens. The axon bifurcates into a rostral (toward the septum) and a caudal (toward the subicular area) branch. Shaded areas represent axon collaterals with synaptic boutons. $(-\boldsymbol{F}$, Reconstructions of the soma and dendrites are shown complete; the axon is shown from selected series of sections as indicated in $\boldsymbol{B}$. The rostral axon enters the triangular septum (TS) through the lateral septum (LSI and LSD) but could not be traced to its termination. The local axon mainly innervates strata oriens (so) and radiatum (sr) but avoids str. lacunosum-moleculare (slm). The caudal axon branch enters the presubiculum from the corpus callosum (fmcc). Diamonds mark connecting points of axonal branches. $\boldsymbol{G}$, Immunofluorescence images of the neurobiotin-filled cell body $\left(\boldsymbol{G}_{1}\right)$ immunopositive for somatostatin $\left(\boldsymbol{G}_{\mathbf{2}}\right)$, calbindin (red, $\left.\boldsymbol{G}_{3}\right)$, and mGluR1 $\alpha$ (the plasma membrane; green, $\boldsymbol{G}_{\mathbf{3}}$ ); a neurobiotin-filled dendrite $\left(\boldsymbol{G}_{\mathbf{4}}\right)$ is decorated by mGluR7a-immunopositive boutons (yellow). $\boldsymbol{H}$, Serial electron microscopic sections of a pyramidal cell dendrite (asterisk) emitting a spine $\left(s ; \boldsymbol{H}_{2}\right)$ and receiving a type ll synapse (arrow) from a neurobiotin-labeled bouton $\left(\boldsymbol{H}_{\mathbf{1}}\right)$. $\boldsymbol{I}$, This cell fires (bottom, orange; filter, $0.8-5 \mathrm{kHz}$ ) around the trough of the theta oscillations recorded extracellularly from a second electrode in the pyramidal layer (filter; $\mathrm{dc}-220 \mathrm{~Hz}$ ). $c \mathrm{c}$, Corpus callosum; IG, indusium griseum; LV, lateral ventricle; PrS, presubiculum; RSG, granular retrosplenial cortex; sp, stratum pyramidale. Scale bars: $\mathbf{C}-\boldsymbol{F}, 100 \mu \mathrm{m} ; \boldsymbol{G}_{1}, 20 \mu \mathrm{m} ; \boldsymbol{G}_{4}, 5 \mu \mathrm{m} ; \boldsymbol{H}_{\boldsymbol{1}}, 0.5 \mu \mathrm{m}$. Calibration: I, $0.5 \mathrm{~s}$, theta, $0.5 \mathrm{mV}$, spikes, $0.5 \mathrm{mV}$.

preferentially at or after the trough $\left(0\right.$ and $\left.360^{\circ}\right)$ of theta cycles, recorded extracellularly in stratum pyramidale (Fig. $5 A$ ), with low discharge frequencies $(0.7 \pm 0.6 \mathrm{~Hz} ; n=5)$ (Table 2). They had a low firing rate during nontheta/nonsharp wave periods $(0.4 \pm 0.5 \mathrm{~Hz} ; n=5)$, but during sharp wave-associated ripple oscillations (Fig. 5B), these cells strongly increased their discharge frequency $(40.2 \pm 20.5 \mathrm{~Hz} ; n=6)$, and most of them fired preferentially on the ascending phase of the single ripple cycles recorded extracellularly in stratum pyramidale (Table 2 ). Interestingly, this spike timing during theta and ripple oscillations is rather similar to that of dendrite-innervating bistratified cells, although bistratified cells are more active during theta oscillations (Klausberger et al., 2004). During gamma oscillations (46 $2 \mathrm{~Hz}$ ), which occurred during theta and also during nontheta/ 


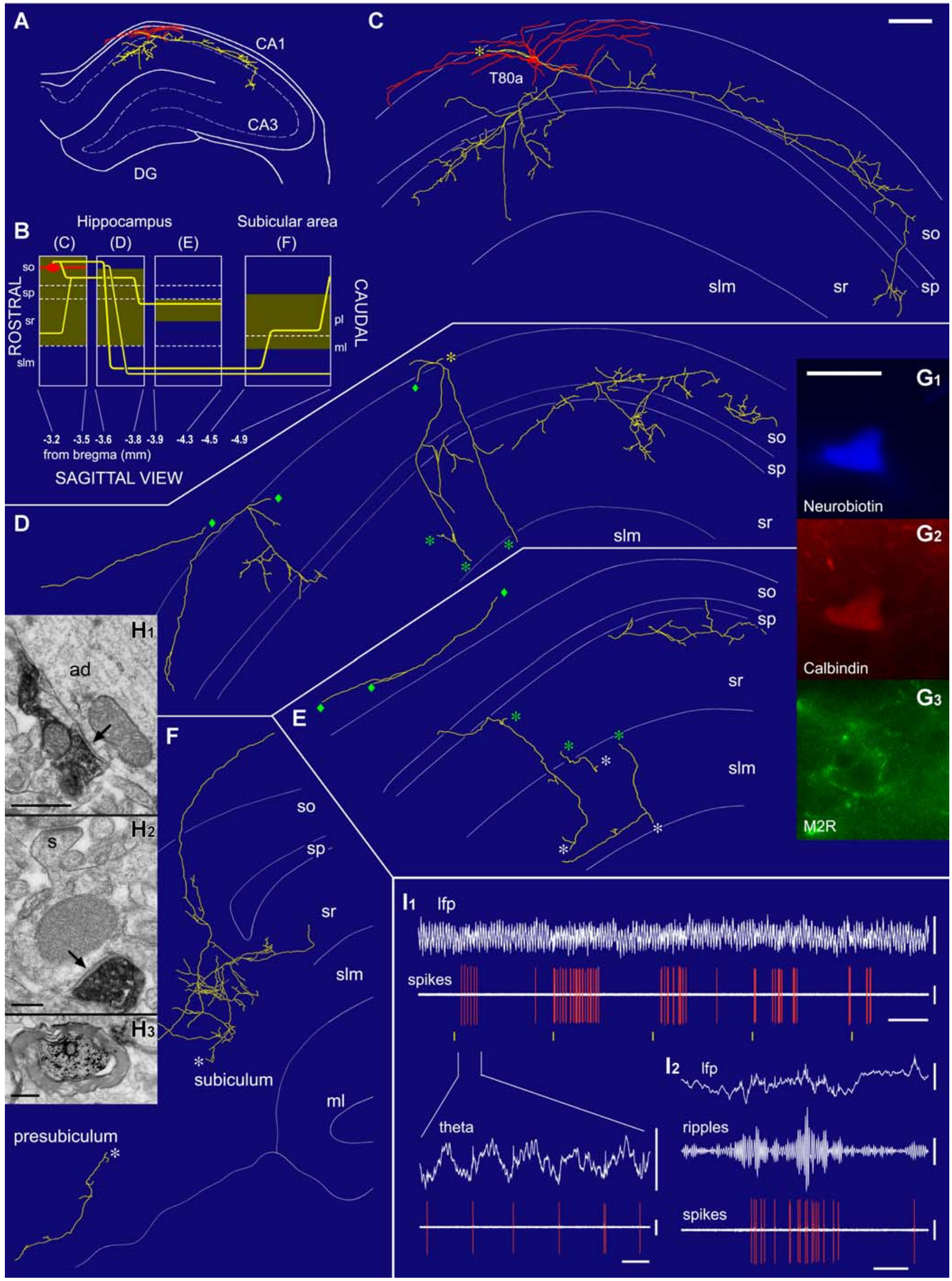


nonsharp wave periods, two cells (T87c, P13c) fired preferentially $(1.4 \mathrm{~Hz})$ (Table 2$)$ on the ascending phase of gamma oscillations ( $p<0.005$; Rayleigh test) (Table 2 ) similar to the majority of putative interneurons recorded in nonanesthetized rats (Csicsvari et al., 2003). Another cell (C25a) fired with a low discharge frequency $(0.2 \mathrm{~Hz})$ and was nonmodulated during gamma oscillations ( $p>0.3$; Rayleigh test). Gamma phase could only be unequivocally evaluated for the above three neurons located in str. oriens (see Materials and Methods).

The two projection neurons in str. radiatum (T74b, T100c) displayed firing patterns different from double-projection cells and oriens-retrohippocampal cells. During theta oscillations, these cells fired with a mean discharge frequency of $5.2 \mathrm{~Hz}$ (Table 2) on the descending phase of the theta cycle (Fig. $5 \mathrm{~A}$ ), similar to PV-expressing basket cells (Klausberger et al., 2003). However, they did not increase their firing rates during sharp waveassociated ripple episodes (Fig. $5 B$ ) (average, $0.7 \mathrm{~Hz} ; n=2$ ), despite their extensive dendritic arbor in the Schaffer collateral/ commissural pathway termination zone, which receives the main excitatory input from the CA3 area. Such a temporal pattern has not been seen either in previously characterized interneuron types (Klausberger et al., 2003, 2004, 2005) or pyramidal neurons. We designate these cells as radiatum-retrohippocampal neurons based on their novel firing pattern and axonal organization.

\section{Postsynaptic targets of GABAergic projection neurons recorded in vivo}

The balance of glutamatergic and GABAergic neurons among the synaptic targets of GABAergic cells determine their overall effect. Hippocampal GABAergic neurons possess specificity of local targets ranging from different domains of pyramidal cells (Somogyi et al., 1998) to predominantly GABAergic neurons (Acsady et al., 1996; Gulyas et al., 1996). To predict the impact on network activity of the cells recorded here, we analyzed their synaptic targets by electron microscopy (Table 3 ).

In the CA1 area, the local postsynaptic targets of four doubleprojection cells were predominantly dendritic shafts of pyramidal neurons $(86 \pm 13 \%$; mean \pm SD) (Fig. $1 H$ ) and, to a lesser extent, interneurons ( $14 \pm 13 \%$; data not shown) both in str. radiatum and str. oriens. The postsynaptic targets of two oriensretrohippocampal projection neurons were also pyramidal cell dendritic shafts (mean, 96\%; $n=33$ synapses, T80a; $n=11$ synapses, K98c). In CA1 str. radiatum, only pyramidal cell dendrites were postsynaptic $(n=10)$ to the double-projection cell located in the CA3 area (C11c), demonstrating a CA3 interneuron to CA1 pyramidal cell GABAergic projection.

Of the 141 identified postsynaptic targets of seven hippocampal GABAergic projection neurons, pyramidal neurons were the dominant targets ( $91 \pm 11 \%$; range, $74-100 \%$; interneurons, $9 \pm$ $11 \%)$. The largest proportion of interneuron targets (26\%) was in the sample of the double-projection cell T87c. We suggest that these targets may represent mainly parvalbumin-positive cells because of their dense unlabeled synaptic input (Gulyas et al., 2003). A previous study reported only CA1 interneuron synaptic targets of hippocampo-septal nonpyramidal cells, labeled in juvenile rats in vitro (Gulyas et al., 2003). The discrepancy may be a result of the developmental stage or a selective survival of cell types in vitro that we did not encounter in vivo.

The postsynaptic targets $(n=29)$ of long-range axons were analyzed in the subiculum. The axon of a radiatumretrohippocampal projection neuron (T74b, $n=13$ synapses) in the subicular molecular layer mainly innervated dendritic shafts, of which $62 \%$ received one or more type 1 synapse and $54 \%$ emitted spines in the analyzed section stacks, making it likely that pyramidal cells were among the targets. Some dendrites with several type 1 synapses originated most likely from interneurons. We could not establish the proportions of pyramidal and interneuron targets, because in the molecular layer of the subiculum, pyramidal cells as well as interneurons probably receive type 1 synapses on their dendritic shafts. Therefore, the criteria used in the CA1 area do not apply in this region. The subicular synaptic targets of a CA1 double-projection cell C25a ( $n=12$ synapses) and the CA3 double-projection cell (C11c; $n=4$ synapses) were in the cellular layers, and some could be unequivocally identified as of pyramidal cell origin by the presence of spines, and few as originating from interneurons, but most remained unidentified. Dendritic spines $(19 \pm 4 \%)$ that also received a type I synapse featured among the subicular targets of all three cells.

\section{Immunofluorescence characterization of retrogradely labeled nonpyramidal projection neurons}

The juxtacellular labeling of cells provides detailed information about individual neurons, but because of the technical challenges of this technique, only a limited sample can be collected. To test how representative our recorded cells were of GABAergic projection neurons, we performed retrograde labeling experiments on a large sample of cells $(n=727)$ identified as projecting either to the septum or the subiculum. All brains $(n=32)$ were tested in serial sections to select those with injection sites confined to the dorsal subiculum $(n=11)$ or medial septum $(n=3)$ (Fig. S1, available at www.jneurosci.org as supplemental material). We carefully checked whether the subicular injection sites did not spread to the adjoining CA1 area. The lack of somatic labeling of local CA1 GABAergic neurons, some with the densest axonal arbors such as basket cells, confirmed that the uptake of the tracer by projection neurons took place outside the CA1 area.

Retrogradely labeled hippocampo-subicular nonpyramidal projection neurons $(n=319)$ were found only ipsilateral to the injection site. In the CA1 area, they were in str. oriens, radiatum, and lacunosum-moleculare (Fig. 6) (Fig. S1 B, available at www. jneurosci.org as supplemental material). Because of the dense labeling of CA1 pyramidal neurons, it was difficult to identify

$\leftarrow$

Figure 2. An oriens-retrohippocampal projection neuron (T80a) recorded in vivo in the dorsal CA1 hippocampal area innervating the subiculum. $\boldsymbol{A}$, The soma (red), dendrites (red), and axon (yellow) in the coronal plane at a rostrocaudal level indicated in $\boldsymbol{B}$. $\boldsymbol{B}$, Schematic representation in the sagittal plane showing the rostrocaudal extent of the cell. The shaded areas represent the distribution of neurobiotin-filled boutons illustrated in $\boldsymbol{C}-\boldsymbol{F}$. $\boldsymbol{C}-\boldsymbol{F}$, The soma and dendrites are shown complete; the axon is shown from a selected section as indicated by blocks in $\boldsymbol{B}$. The local axon mainly innervates strata oriens (so), pyramidale (sp), and radiatum (sr) but mostly avoids str. lacunosum-moleculare (slm). The long-range axon collaterals pass through str. lacunosum-moleculare, extensively branch in the pyramidal layer of the subiculum, and enter the presubiculum. Asterisks and diamonds mark connecting points of axonal branches. $\mathbf{G}$, Images of the neurobiotin-filled cell

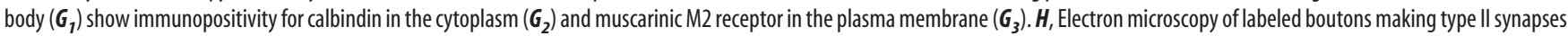
(arrows) onto an apical dendrite (ad; $\boldsymbol{H}_{\mathbf{7}}$ ) and a small spiny $(s)$ dendrite $\left(\boldsymbol{H}_{2}\right)$ of CA1 pyramidal neurons; myelinated main axon of the cell in the subicular molecular layer $\left(\boldsymbol{H}_{\mathbf{3}}\right) . \boldsymbol{I}$, In vivo recording shows that the cell becomes active rhythmically at $0.1 \mathrm{~Hz}\left(\boldsymbol{I}_{\boldsymbol{1}}\right)$ during theta oscillations; yellow lines mark $10 \mathrm{~s}$ intervals. The cell fires around the trough of theta oscillations $\left(\boldsymbol{I}_{\boldsymbol{1}}\right)$ recorded from the same electrode. During ripple episodes, the cell strongly increases its firing rate ( $\boldsymbol{I}_{\mathbf{2}}$; top, filter dc-220 Hz; middle, $90-140 \mathrm{~Hz}$ bandpass; bottom, $0.8-5 \mathrm{kHz}$ ). Scale bars: (in $\boldsymbol{C}$ ) $\boldsymbol{C}-\boldsymbol{F}, 100 \mu \mathrm{m}$; (in $\boldsymbol{G}_{\mathbf{1}}$ ) $\boldsymbol{G}_{\mathbf{1}}-\boldsymbol{G}_{\mathbf{3}}$, $20 \mu \mathrm{m} ; \boldsymbol{H}_{1}, 0.5 \mu \mathrm{m} ; \boldsymbol{H}_{2}, 0.2 \mu \mathrm{m} ; \boldsymbol{H}_{3}, 0.5 \mu \mathrm{m}$. Calibration: $\boldsymbol{I}_{\boldsymbol{1}}, 4 \mathrm{~s}$ (inset, $0.2 \mathrm{~s}$ ); Ifp, $1 \mathrm{mV}$; theta, $1 \mathrm{mV}$; spikes, $1 \mathrm{mV} ; \boldsymbol{I}_{2}, 0.2 \mathrm{~s} ;$ Ifp, $1 \mathrm{mV}$; ripples, $0.1 \mathrm{mV}$; spikes, $1 \mathrm{mV}$. 

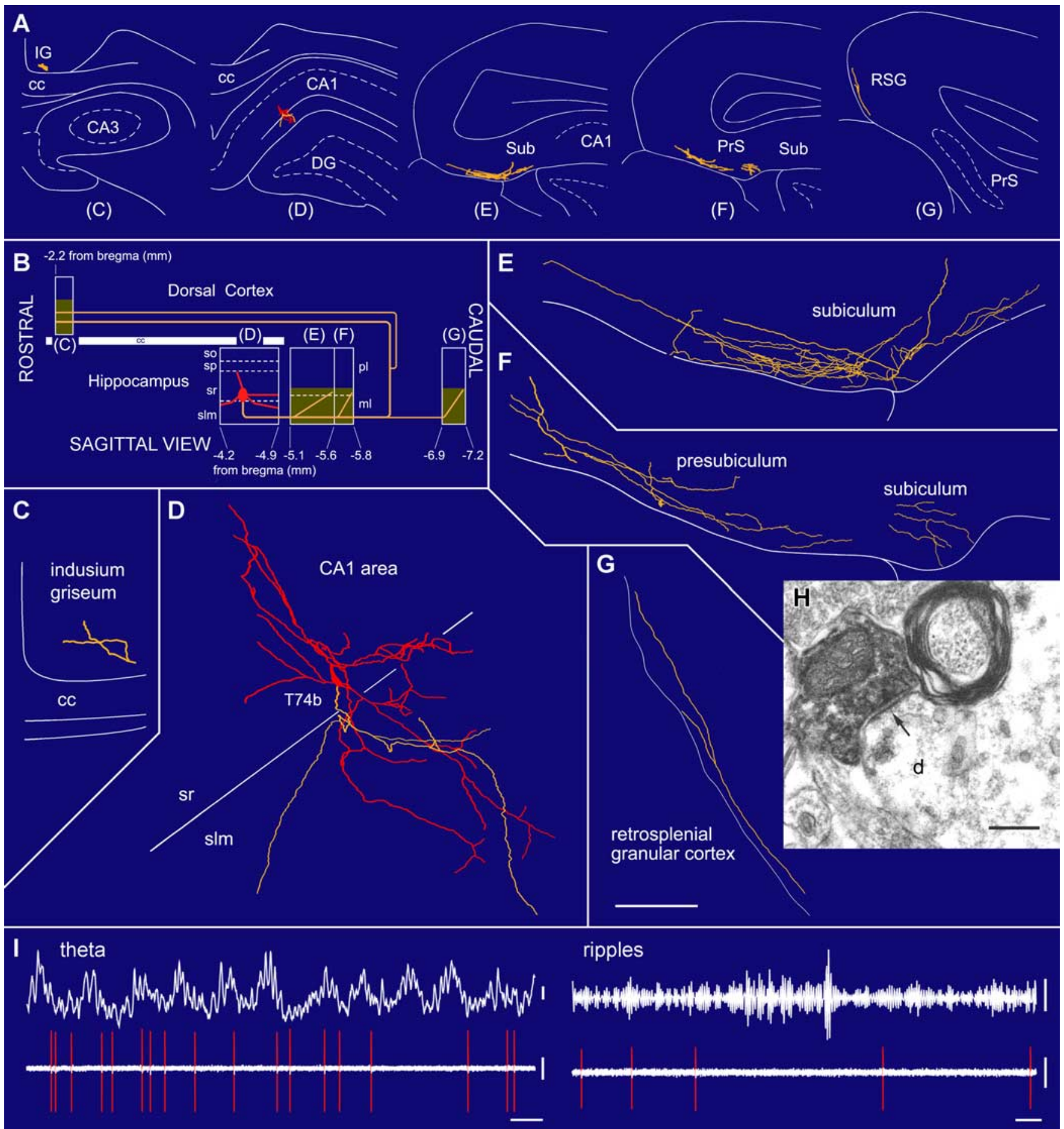

Figure 3. A radiatum-retrohippocampal projection neuron (T74b) recorded in vivo in the dorsal CA1 area innervating the subiculum (Sub), presubiculum (PrS), retrosplenial cortex (RSG), and indusium griseum (IG). $\boldsymbol{A}$, The soma (red), dendrites (red), and axons (yellow) in coronal planes from selected sections as indicated in $\boldsymbol{B}$. $\boldsymbol{B}$, Representation in the sagittal plane showing the rostrocaudal extent of the dendrites and axon. The soma is located at the border of str. radiatum and lacunosum-moleculare. The axon, traced over $5 \mathrm{~mm}$, runs toward caudal regions through the subiculum and presubiculum and then bifurcates into additional caudal and rostral branches. Shaded areas represent the distribution of boutons in the reconstructed sections. $\mathbf{C}-\mathbf{G}$, Soma and dendrites are shown complete; the axon is shown from selected sections (blocks in $\boldsymbol{B}$ ), with very few local collaterals within the hippocampus. The long-range axon innervates the molecular layer in the subiculum and other caudal areas such as the retrosplenial granular cortex. $\boldsymbol{H}$, Electron micrograph of a neurobiotin-filled bouton making a type ll synapse (arrow) with a dendritic shaft that also receives a type I synapse in the subiculum. II In vivo firing patterns show that the cell fires at the descending phase of extracellular theta oscillations (filter, direct current-220 Hz) recorded from a second electrode in the pyramidal layer. During ripple episodes (top right, $90-140 \mathrm{~Hz}$ bandpass), the cell did not increase its firing. cc, Corpus callosum; slm, str. lacunosum-moleculare; so, str. oriens; sp, str. pyramidale; sr, str. radiatum. Scale bars: (in G) $\mathbf{C}-\mathbf{G}, 100 \mu \mathrm{m} ; \boldsymbol{H}, 0.2 \mu \mathrm{m}$. Calibration: $\boldsymbol{I}$, theta, $0.2 \mathrm{mV}$; ripples, $0.05 \mathrm{mV}, 0.1 \mathrm{~s}$; spikes, $0.5 \mathrm{mV}$.

nonpyramidal projection neurons in str. pyramidale. Only a few cells were detected in the CA3 area and in the dentate gyrus (Fig. $\mathrm{S} 1 C, D$, available at www.jneurosci.org as supplemental material). Each cell was immunocytochemically tested for the expression of three to six molecular markers (Table 4) (Table S1, available at www.jneurosci.org as supplemental material). In CA1 str. oriens, SOM (50\%), mGluR1 $\alpha$ (55\%), or M2R (51\%) were detected in approximately half of hippocampo-subicular neurons. One com- 

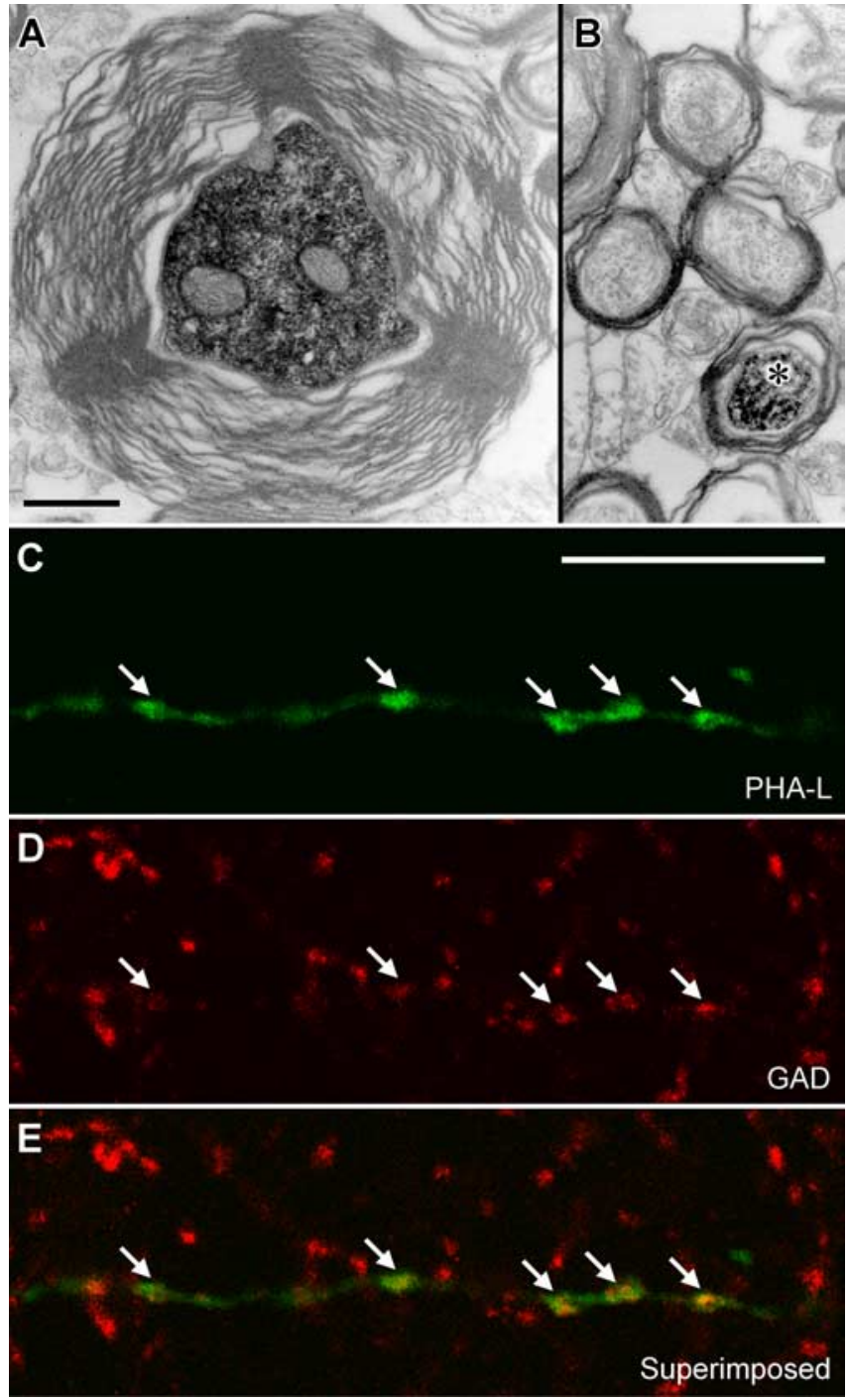

Figure 4. Axonal projections of hippocampal long-range GABAergic neurons. $\boldsymbol{A}$, The main axon of the presumed double-projection cell D150 heading toward the subiculum in the CA1 alveus. Caudally, the axon divided into two branches of smaller but approximately equal diameter, and this diameter was taken as the projection axon diameter. One of the collaterals ran in the white matter of the subiculum until the neurobiotin faded, and it could not be followed to the terminals. The other turned back from the subiculum and proceeded in the white matter rostrally to the $\mathrm{CA} 1$ area, where it provided boutons to both str. oriens and radiatum. $\boldsymbol{B}$, The neurobiotin-labeled main axon of an identified CA1 pyramidal cell (asterisk) in the white matter of the subiculum surrounded by similar axons. Note the difference in axon diameter and myelin thickness. $\boldsymbol{C}-\boldsymbol{E}$, An anterogradely labeled axon $(\boldsymbol{C})$ in the subiculum after PHA-L (green) injection into the $C A 1$ area is positive for $G A D$ (D, red). Scale bars: (in $A) A, B, 0.5 \mu \mathrm{m}$; (in $C) C-E, 10$ $\mu \mathrm{m}$.

mon subset of hippocampo-subicular projection neuron in str. oriens was positive for $\mathrm{mGluR} 1 \alpha$ and SOM but negative for M2R (Fig. $6 A_{1}-A_{5}$ ) (Table S2, available at www.jneurosci.org as supplemental material). The other frequently seen subset in this layer was positive for M2R but negative for SOM, CB, and usually mGluR1 $\alpha$ (Fig. $6 B_{1^{-}-B_{5}}$ ) (Table S2, available at www.jneurosci.org as supplemental material) In the CA1 str. radiatum, approximately half $(47 \%)$ of hippocampo-subicular projection neurons were positive for M2R, and one-quarter (26\%) were positive for mGluR $1 \alpha$. The expression of M2R and $\mathrm{mGluR} 1 \alpha$ was mostly mutually exclusive (Fig, $6 C_{1}-C_{5}$ ). In the CA1 str. lacunosum-moleculare, mGluR $1 \alpha$ was expressed in $23 \%$ of hippocampo-subicular projection neurons, and they were usu-
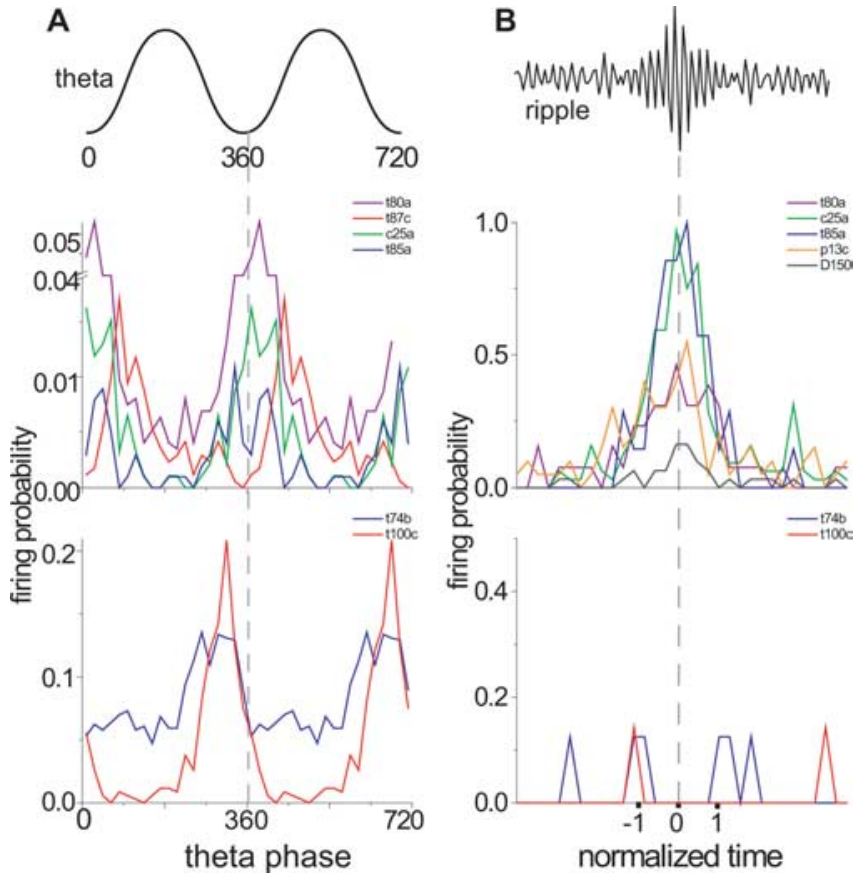

Figure 5. Comparison of the firing patterns of nonpyramidal projection neurons located in the CA1 str. oriens or radiatum/lacunosum-moleculare during theta oscillations and ripple episodes. The firing probability per bin (size $18^{\circ}$ ) of each projection neuron is represented by different colors. $\boldsymbol{A}$, The data are duplicated over two theta cycles to represent rhythmicity. Double-projection cells (T87c, C25a) and oriens-retrohippocampal projection cells (T80a, T85a, K98c) fire with highest probability during or after the trough of theta oscillations ( 0 and $360^{\circ}$ ) recorded extracellularly in str. pyramidale. A previously published subiculum projecting cell, T85a (Ferraguti et al., 2005), is added for comparison. Radiatum-retrohippocampal projection cells located at the border of str. radiatum/lacunosum-moleculare (T74b, T100c) fire with highest probability just before the trough of theta oscillations. $\boldsymbol{B}$, During ripple episodes, the average firing probability of double projection cells (C25a, P13C, D150) and oriens-retrohippocampal projection cells (T80a, T85a, K98c) increases. In contrast, radiatum-retrohippocampal cells (T74b, T100c) show no increase in firing probability. The start, highest amplitude, and end of the normalized ripple episode are marked as $-1,0$, and 1, respectively.

ally negative for other tested molecules (Fig. $6 D_{1}-D_{5}$ ). A small proportion (16 of 319) of hippocampo-subicular neurons in the CA1 str. radiatum and lacunosum-moleculare were negative for all five tested molecules. In the CA3 str. radiatum and lacunosum-moleculare, the SOM, NPY, or M2R were detected in approximately half of hippocampo-subicular neurons (Table 4), respectively. In the hilus, the majority of tested hippocamposubicular projection neurons were positive for SOM and NPY, and they were all negative for $\mathrm{CB}$ (Fig. $6 E_{1}-E_{5}$ ). No, or very few, nonpyramidal projection neurons were positive for PV, CCK, VIP, CR, or NOS, although these molecules are expressed by prominent GABAergic interneuron classes.

The laminar distributions of hippocampo-septal projection neurons $(n=408)$ (Table 4) (Fig. S1 $E-H$, available at www.jneurosci.org as supplemental material) were similar to those reported previously. In CA1 str. oriens, hippocampo-septal neurons were SOM- (94\%) and mGluR1 $\alpha$-positive (68\%) (Table 4) (Table S2, available at www.jneurosci.org as supplemental material). The majority of these cells $(75 \%)$ were M2R negative (Fig. $\left.6 F_{1}-F_{5}\right)$. In the CA3 area, SOM (93\%) and mGluR $1 \alpha(84 \%)$ were detected in most hippocampo-septal neurons. In addition, CR was expressed in 6 of 10 tested hippocampo-septal neurons in the CA3 str. lucidum (Fig. $6 G_{1}-G_{5}$ ) and in a few hilar septally projecting cells $(3 / 14)$, but CR was not detected in hippocamposubicular neurons. In the hilus, virtually all hippocampo-septal 
Table 2. Firing frequencies and phases of nonpyramidal projection neurons in different network states recorded in vivo

\begin{tabular}{|c|c|c|c|c|c|c|c|c|c|}
\hline \multirow[b]{2}{*}{ Cell number } & \multirow[b]{2}{*}{ Type } & \multirow[b]{2}{*}{ Soma } & \multicolumn{4}{|c|}{ Discharge frequency (in $\mathrm{Hz}$ ) } & \multirow[b]{2}{*}{ Theta phase $^{d}$} & \multirow{2}{*}{$\begin{array}{l}\text { Ripple } \\
\text { phase }^{d}\end{array}$} & \multirow[b]{2}{*}{ Gamma phase $^{d}$} \\
\hline & & & Theta & Ripples & $\mathrm{nt} / \mathrm{nr}$ & $\overline{G a m m a}$ & & & \\
\hline T87c & double-projection & CA1so & 1.5 & n.o. & n.o. & 0.9 & $131 \pm 85^{\circ}$ & n.o. & $122 \pm 73^{\circ}$ \\
\hline $\mathrm{C} 25 \mathrm{a}$ & double-projection & CA1so & 0.3 & 46.8 & 0.1 & 0.3 & $23 \pm 41^{\circ}$ & $56 \pm 43^{\circ}$ & m.n.s. \\
\hline $\mathrm{D} 150^{\circ}$ & double-projection & CA1so & n.o. & 10.2 & n.o. & n.o. & n.o. & $74 \pm 73^{\circ}$ & n.o. \\
\hline $\mathrm{P} 13 \mathrm{C}$ & double-projection & CA1so & n.o. & 23.8 & 1.0 & 1.8 & n.o. & $290 \pm 70^{\circ}$ & $79 \pm 79^{\circ}$ \\
\hline K98c & oriens-retrohippocampal & CA1so & 0.3 & 48.0 & 0.9 & n.o. & $71 \pm 44^{\circ}$ & n.o. & n.o. \\
\hline T80a & oriens-retrohippocampal & CA1so & 1.1 & 43.1 & 0.1 & n.o. & $16 \pm 52^{\circ}$ & n.o. & n.o. \\
\hline T85a ${ }^{b}$ & oriens-retrohippocampal & CA1so & 0.2 & 69.0 & 0.1 & n.o. & $358 \pm 53^{\circ}$ & $122 \pm 60^{\circ}$ & n.o. \\
\hline $\mathrm{T} 74 \mathrm{~b}$ & radiatum-retrohippocampal & CA1sr & 6.7 & 1.4 & 0.8 & n.o. & $290 \pm 90^{\circ}$ & n.o. & n.o. \\
\hline $\mathrm{T} 100 \mathrm{C}$ & radiatum-retrohippocampal & CA1sim & 3.6 & 0 & 3.0 & n.o. & $306 \pm 32^{\circ}$ & n.o. & n.o. \\
\hline $\mathrm{C} 11 c^{c}$ & double-projection & CA3sp & n.o. & n.o. & n.o. & n.o. & n.o. & n.o. & n.o. \\
\hline
\end{tabular}

m.n.s., Modulation not significant; n.o., not observed; nt/nr, nontheta/nonripple periods.

${ }^{a}$ D150 was intracellularly recorded with a sharp electrode.

${ }^{b}$ T85a has been reported as a trilaminar cell in a previous study (Ferraguti et al., 2005).

'C11c, no sufficient data were recorded for firing.

${ }^{d}$ Mean \pm angular deviation.

Table 3. Postsynaptic targets of in vivo recorded nonpyramidal projection neurons

\begin{tabular}{|c|c|c|c|c|c|c|c|}
\hline \multirow[b]{3}{*}{ Cell no. } & \multirow[b]{3}{*}{ Cell type } & \multirow[b]{3}{*}{ Soma } & \multirow{3}{*}{$\begin{array}{l}\text { Hippocampal } \\
\text { axon }\end{array}$} & \multicolumn{4}{|c|}{ Axonal targets in the CA1 area } \\
\hline & & & & \multirow{2}{*}{$\begin{array}{l}\text { Nos. of synapses } \\
\text { tested }^{a}\end{array}$} & \multicolumn{3}{|c|}{ Postsynaptic targets (\%) } \\
\hline & & & & & Pyramidal cell & Interneuron & Unidentified \\
\hline \multirow[t]{3}{*}{$\mathrm{T} 87 \mathrm{c}$} & \multirow[t]{3}{*}{ double-projection } & \multirow[t]{3}{*}{ CA1so } & \multirow[t]{3}{*}{ CA1so, sp, sr } & total (25) & 68 & 24 & 8 \\
\hline & & & & so (13) & 54 & 38 & 8 \\
\hline & & & & $\mathrm{sp}, \mathrm{sr}(12)$ & 83 & 8 & 8 \\
\hline \multirow[t]{3}{*}{$\mathrm{C} 25 \mathrm{a}$} & \multirow[t]{3}{*}{ double-projection } & \multirow[t]{3}{*}{ CA1so } & \multirow[t]{3}{*}{ CA1so, sp, sr } & total (16) & 88 & 6 & 6 \\
\hline & & & & so $(10)$ & 90 & 0 & 10 \\
\hline & & & & $s p, s r(6)$ & 83 & 17 & 0 \\
\hline \multirow[t]{3}{*}{ D150 } & \multirow[t]{3}{*}{ double-projection } & \multirow[t]{3}{*}{ CA1so } & \multirow[t]{3}{*}{ CA1so, sp, sr } & total (39) & 69 & 21 & 10 \\
\hline & & & & so (18) & 67 & 28 & 5 \\
\hline & & & & $\mathrm{sp}, \mathrm{sr}(21)$ & 71 & 14 & 14 \\
\hline \multirow[t]{3}{*}{$\mathrm{P} 13 \mathrm{C}$} & \multirow[t]{3}{*}{ double-projection } & \multirow[t]{3}{*}{ CA1so } & \multirow[t]{3}{*}{ CA1so, sp, sr } & total (15) & 93 & 0 & 7 \\
\hline & & & & so (3) & 100 & 0 & 0 \\
\hline & & & & $\mathrm{sp}, \mathrm{sr}(12)$ & 92 & 0 & 8 \\
\hline \multirow[t]{3}{*}{ T80a } & \multirow{3}{*}{ oriens-retrohippocampal } & \multirow[t]{3}{*}{ CA1so } & \multirow[t]{3}{*}{ CA1so, sp, sr } & total (36) & 83 & 8 & 8 \\
\hline & & & & so (12) & 83 & 8 & 8 \\
\hline & & & & $\mathrm{sp}, \mathrm{sr}(24)$ & 83 & 8 & 8 \\
\hline \multirow[t]{3}{*}{ K98c } & \multirow[t]{3}{*}{ oriens-retrohippocampal } & \multirow[t]{3}{*}{ CA1so } & \multirow[t]{3}{*}{ CA1so, sp, sr } & total (11) & 100 & 0 & 0 \\
\hline & & & & so (4) & 100 & 0 & 0 \\
\hline & & & & $\mathrm{sp}, \mathrm{sr}(7)$ & 100 & 0 & 0 \\
\hline $\mathrm{C} 11 \mathrm{c}$ & double-projection & CA3sp & $\begin{array}{l}\text { CA1sp, sr, } \\
\text { CA3so, sp, sr }\end{array}$ & $\mathrm{sp}, \mathrm{sr}(12)$ & 83 & 0 & 17 \\
\hline
\end{tabular}

${ }^{a}$ Numbers in parentheses denote the number of postsynaptic cellular profiles that were tested with electron microscopy.

projection neurons were positive for SOM (100\%) and NPY (92\%) but negative for $\mathrm{CB}$ (Fig. $6 \mathrm{H}_{1}-\mathrm{H}_{5}$ ); such cells were also frequent among the hippocampo-subicular projection neurons, raising the possibility that the same cells innervate both regions (see above).

\section{Molecular expression profiles of hippocampo-subicular and hippocampo-septal projection neurons}

To test whether specific molecular expression profiles are associated with the target area of projection neurons, we focused on $\mathrm{SOM}, \mathrm{mGluR} 1 \alpha$, and M2R in CA1 str. oriens, because they were common markers of hippocampo-subicular and hippocamposeptal projection neurons (Table 4) (Table S2, available at www.jneurosci.org as supplemental material). The most common subset was SOM-positive/mGluR1 $\alpha$-positive/M2R-negative both among hippocampo-subicular (40\%) (Fig. $6 A_{1}-A_{5}$ ) and hippocampo-septal neurons $(46 \%)$ (Fig. $\left.6 F_{1}-F_{5}\right)$. The expressions of SOM and mGluR $1 \alpha$ in CA1 str. oriens were significantly associated in the hippocampo-subicular neurons $\left(\chi^{2}\right.$ test; $p<$ $0.0005)$. Although there was a higher proportion of hippocamposeptal projection cells positive for both SOM and mGluR1 $\alpha$ (66 vs $52 \%$ of hippocampo-subicular), $30 \%$ of SOM-positive hippocampo-septal cells were mGluR $1 \alpha$ negative. Furthermore, the expressions of mGluR $1 \alpha$ and M2R were mostly mutually exclusive $(p<0.05)$ in both populations. Therefore, SOMpositive/mGluR1 $\alpha$-positive/M2R-negative cells can project to both the subiculum and the medial septum. To prove that the same cell innervates both areas will require double retrogradelabeling experiments. Single-cell axonal visualization revealed already that two in vivo recorded double-projection cells exhibited this molecular profile (T87c, C25a). One additional in vivo recorded double-projection cell was SOM-positive/mGluR $1 \alpha$ - 

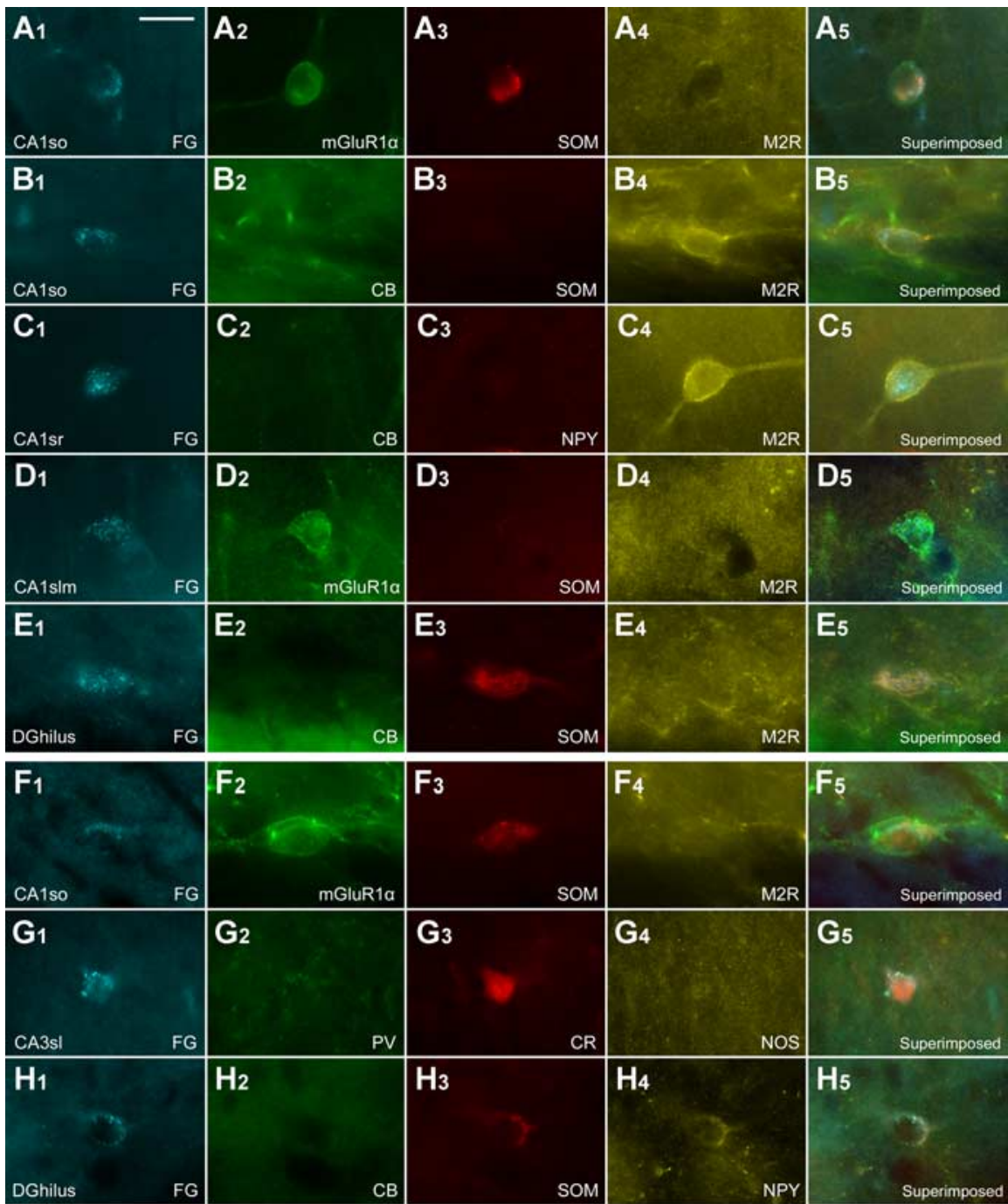

sis

$I_{1}$

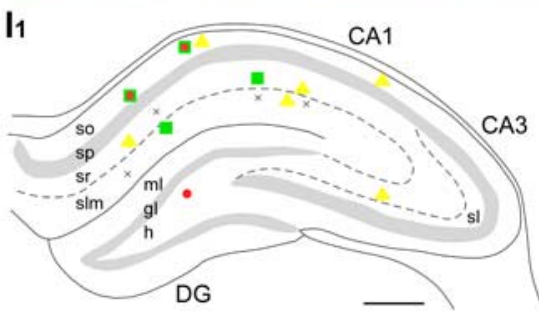

$I_{2}$

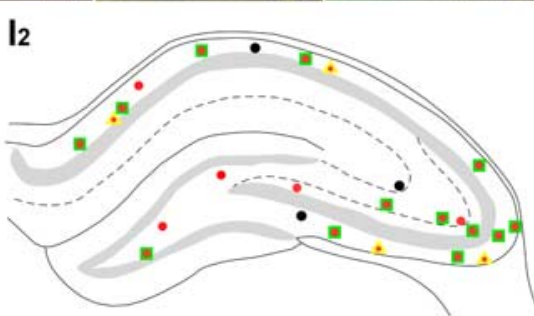

- SOM only; ImGluR1a only; M2R only:

Figure 6. Molecular characterization of nonpyramidal projection neuron populations. $\boldsymbol{A}-\boldsymbol{H}$, Fluorescence digital micrographs of retrogradely labeled neurons after $F G$ injection into the subiculum $(\boldsymbol{A}-\boldsymbol{E})$ or the medial septum $(\boldsymbol{F}-\boldsymbol{H}) \cdot \boldsymbol{A}$, In str. oriens of the CA1 area, a retrogradely labeled hippocampo-subicular projection cell is immunoreactive for $\operatorname{mGluR1} \alpha\left(A_{2}\right)$ and $\operatorname{SOM}\left(A_{3}\right)$ but negative for muscarinic $\operatorname{M2R}\left(\boldsymbol{A}_{4}\right)$. This expression profile is common for both hippocampo-subicular and hippocampo-septal neurons. $\boldsymbol{B}$, Another hippocampo-subicular projection neuron $\left(\boldsymbol{B}_{1}\right)$ is negative for $\mathrm{CB}\left(\boldsymbol{B}_{2}\right)$ and $\operatorname{SOM}\left(\boldsymbol{B}_{3}\right)$ but positive for M2R $\left(\boldsymbol{B}_{4}\right)$. $\boldsymbol{C}$, In str. radiatum (CA1sr), a hippocampo-subicular projection neuron $\left(\boldsymbol{C}_{\mathbf{1}}\right)$ shows M2R immunoreactivity $\left(\boldsymbol{C}_{4}\right)$ but is negative for $C B\left(\boldsymbol{C}_{2}\right)$ and NPY $\left(\boldsymbol{C}_{3}\right)$. D, In str. lacunosum-moleculare (CA1 slm), a retrogradely labeled hippocampo-subicular cell $\left(\boldsymbol{D}_{1}\right)$ is positive for mGluR1 $\alpha\left(\boldsymbol{D}_{2}\right)$ butnegative for SOM $\left(\boldsymbol{D}_{3}\right)$ and $\mathrm{M} 2 \mathrm{R}\left(\boldsymbol{D}_{\mathbf{4}}\right)$. $\boldsymbol{E}$, A hippocampo-subicular projection neuron $\left(\boldsymbol{E}_{7}\right)$ in the dentate hilus (DG hilus) is SOM positive $\left(\boldsymbol{E}_{3}\right)$ but $\mathrm{CB}$ negative $\left(\boldsymbol{E}_{2}\right)$ and M2R negative $\left(\boldsymbol{E}_{4}\right) \cdot \boldsymbol{F}$, A hippocampo-septal projection neuron $\left(\boldsymbol{F}_{7}\right)$ in the CA1so is positive for mGluR1 $\alpha\left(\boldsymbol{F}_{2}\right)$ and SOM $\left(\boldsymbol{F}_{3}\right)$ but not for M2R $\left(\boldsymbol{F}_{4}\right)$. This expression profile is also frequently seen in hippocampo-subicular neurons. $\boldsymbol{G}$, In str. lucidum of the $C A 3$ area $(C A 3 \mathrm{sl})$, a hippocampo-septal projection neuron $\left(\boldsymbol{G}_{\mathbf{f}}\right)$ is $(\mathrm{R}$ positive $\left(\boldsymbol{G}_{3}\right)$ but PV $\left(\boldsymbol{G}_{2}\right)$ and NOS negative $\left(\boldsymbol{G}_{\mathbf{4}}\right)$. $\boldsymbol{H}$, In the dentate hilus, a hippocampo-septal neuron $\left(\boldsymbol{H}_{7}\right)$ is positive for SOM $\left(\boldsymbol{H}_{3}\right)$ and $\operatorname{NPY}\left(\boldsymbol{H}_{\boldsymbol{4}}\right)$ but negative for $\mathrm{CB}\left(\boldsymbol{H}_{2}\right)$. This expression profile is also found in hilar hippocampo-subicular projection cells. $\boldsymbol{I}$, Distributions of retrogradely labeled GABAergic neurons projecting to the subicular $\left(\boldsymbol{I}_{\boldsymbol{l}}\right)$ and septal $\left(\boldsymbol{I}_{\boldsymbol{l}}\right)$ areas. Each panel represents a 70- $\mu \mathrm{m}$-thick triple-immunofluorescence-labeled section for SOM, mGluR1 $\alpha$, and M2R. $I_{1}$, Hippocampo-subicular neurons are mainly present in the $\mathrm{CA} 1$ area and rare in the $\mathrm{C} A 3$ area and dentate gyrus. In the $\mathrm{CA} 1$ area, they are in str. oriens (so), radiatum (sr), and lacunosum-moleculare (sIm). In this area, SOM-positive/mGluR1 $\alpha$-positive/M2R-negative projection cells are located in the str. oriens, SOM-negative/mGluR1 $\alpha$-negative/M2R-positive cells are present throughout all layers, and SOM-negative/
negative/M2R-positive (P13c). This profile represented $21 \%$ of hippocamposeptal cells but was not encountered among the hippocampo-subicular retrogradely labeled cells. The in vivo recorded oriens-retrohippocampal cell K98c may belong to this group, but it could also belong to M2R-negative cells (Table S1, available at www.jneurosci.org as supplemental material).

Because the expression of mGluR $1 \alpha$ and SOM in hippocampo-subicular neurons were overlapped, as mentioned above, mGluR $1 \alpha$-negative hippocamposubicular cells were expected to be SOM negative. In the CA1 str. oriens, SOM-negative/mGluR1 $\alpha$-negative/M2R-positive hippocampo-subicular neurons were common (29\%) (Fig. $6 B_{1}-B_{5}$ ) but absent among the hippocampo-septal neurons, excluding double-projection by this subset of cells. Indeed, two in vivo recorded oriensretrohippocampal projection cells (T85a, T80a) showed similar profiles, although T80a was not tested for SOM.

The laminar location of the cell bodies of projection neurons also showed target area-specific distributions. In the CA1 str. radiatum and lacunosum-moleculare, only hippocampo-subicular, but not hippocampo-septal, neurons were found (Fig. 6I, Table 4). Two in vivo recorded cells in the CA1 strata radiatum and lacunosum-moleculare actually sent their axons to the retrohippocampal areas without septally projecting axons (T74b, T100c). In contrast, there were numerous hippocampo-septal neurons but few hippocampo-subicular neurons in the CA3 area. Interneurons in the pyramidal cell layer could not be sampled sufficiently because of the high density of labeled pyramidal cells.

\section{Discussion}

\section{Diversity of GABAergic projection cell types}

We demonstrated several novel GABAergic interareal projections in the temporal

\section{$\leftarrow$}

mGluR1 $\alpha$-positive/M2R-negative cells are distributed in str. radiatum and lacunosum-moleculare. Some hippocamposubicular neurons are immunonegative for all three molecules. $\boldsymbol{I}_{2}$, Hippocampo-septal neurons are scattered throughout the hippocampus. In the CA1 area, most of them are in str. oriens. In the CA3 area, they are in all of the layers; in the dentate gyrus, they are restricted to the hilus. Virtually all hippocampo-septal neurons are SOM positive. The majority of them are SOM positive/mGluR1 $\alpha$ positive/M2R negative. In addition, there are also some triple-positive cells and SOMpositive/mGluR1 $\alpha$-negative/M2R-positive cells. Scale bars: (in $\boldsymbol{A}) \boldsymbol{A}-\boldsymbol{H}, 20 \mu \mathrm{m} ; \boldsymbol{I}, 500 \mu \mathrm{m}$. 
Table 4. Hippocampo-subicular and hippocampo-septal projection neurons immunocytochemically tested for molecules expressed by GABAergic cells

\begin{tabular}{|c|c|c|c|c|c|c|c|c|c|c|c|c|c|c|c|c|c|c|c|c|c|c|c|}
\hline & \multicolumn{11}{|c|}{ Molecular expression of hippocampo-subicular neurons } & & \multicolumn{11}{|c|}{ Molecular expression of hippocampo-septal neurons } \\
\hline & PV & св & $\mathrm{CR}$ & som & NPY & $\mathrm{CCK}$ & VIP & NOS & MER & $\begin{array}{c}\mathrm{mG} \text { luR } \\
1 \alpha\end{array}$ & $\begin{array}{l}\mathrm{mG} \text { luR } \\
\text { 8a input }\end{array}$ & & PV & Св & $\mathrm{CR}$ & SoM & NPY & $\mathrm{CCK}$ & VIP & Nos & $\mathrm{M} 2 \mathrm{R}$ & $\frac{\mathrm{mGG} \text { LuR }}{1 \alpha}$ & $\begin{array}{c}\text { mG luR } \\
8 \mathrm{a} \text { input }\end{array}$ \\
\hline Total (319) & $\begin{array}{c}4 \\
(378)\end{array}$ & $\begin{array}{c}14 \\
(27789)\end{array}$ & $\begin{array}{c}0 \\
\text { (040) }\end{array}$ & $\begin{array}{c}30 \\
(34113)\end{array}$ & $\begin{array}{r}24 \\
(33140)\end{array}$ & $\begin{array}{c}4 \\
(255)\end{array}$ & $\begin{array}{c}0 \\
0 \\
\text { (033) }\end{array}$ & $\begin{array}{c}0 \\
(046)\end{array}$ & $\begin{array}{c}42 \\
(10257)\end{array}$ & $\begin{array}{c}38 \\
(2669)\end{array}$ & $\begin{array}{c}7 \\
(229)\end{array}$ & Total $(408)$ & \begin{tabular}{|c}
8 \\
88100
\end{tabular} & $\begin{array}{c}26 \\
(2388)\end{array}$ & $\begin{array}{c}18 \\
\text { (1265) }\end{array}$ & $\begin{array}{c}95 \\
(1902011)\end{array}$ & $\begin{array}{c}41 \\
(3688)\end{array}$ & $\begin{array}{c}2 \\
(285)\end{array}$ & $\begin{array}{c}2 \\
(288)\end{array}$ & $\begin{array}{c}1 \\
(11006)\end{array}$ & $\begin{array}{c}36 \\
(81224)\end{array}$ & $\begin{array}{c}668 \\
(6595)\end{array}$ & $\begin{array}{c}3 \\
\text { (134) }\end{array}$ \\
\hline CAl total (290) & $\begin{array}{c}3 \\
(2 / 2)\end{array}$ & $\begin{array}{c}13 \\
(23371)\end{array}$ & $\begin{array}{l}0 \\
\text { (035) }\end{array}$ & $\begin{array}{c}27 \\
(28103)\end{array}$ & $\begin{array}{c}20 \\
(26128)\end{array}$ & $\begin{array}{c}4 \\
(251)\end{array}$ & $\begin{array}{c}0 \\
0 \\
\text { (0311) }\end{array}$ & $\begin{array}{c}0 \\
(040)\end{array}$ & $\begin{array}{c}43 \\
(1011234)\end{array}$ & $\begin{array}{c}40 \\
(2665)\end{array}$ & $\begin{array}{c}7 \\
\text { (229) }\end{array}$ & CAl total (129) & $\mid \begin{array}{c}3 \\
(129)\end{array}$ & $\begin{array}{c}32 \\
(928)\end{array}$ & $\begin{array}{c}6 \\
\text { (1196) }\end{array}$ & $\begin{array}{c}94 \\
(2266)\end{array}$ & $\begin{array}{c}46 \\
(1328)\end{array}$ & $\begin{array}{c}0 \\
(025)\end{array}$ & $\begin{array}{c}0 \\
0 \\
(025)\end{array}$ & $\begin{array}{c}0 \\
(029)\end{array}$ & $\begin{array}{c}40 \\
\text { (31178) }\end{array}$ & $\begin{array}{c}69 \\
(27399)\end{array}$ & $\begin{array}{c}13 \\
(18)\end{array}$ \\
\hline so (139) & $\begin{array}{c}3 \\
(132)\end{array}$ & $\begin{array}{c}27 \\
\text { (1971) }\end{array}$ & $\begin{array}{c}0 \\
\text { (01013) }\end{array}$ & $\begin{array}{c}50 \\
(2850)\end{array}$ & $\begin{array}{c}36 \\
(2055)\end{array}$ & $\begin{array}{c}0 \\
(027)\end{array}$ & $\begin{array}{c}0 \\
\text { (0112) }\end{array}$ & $\begin{array}{c}0 \\
\text { (019) }\end{array}$ & $\begin{array}{c}51 \\
(531003)\end{array}$ & $\begin{array}{c}55 \\
(1883)\end{array}$ & $\begin{array}{c}18 \\
(211)\end{array}$ & so (126) & $\begin{array}{c}3 \\
(129)\end{array}$ & $\begin{array}{c}32 \\
(928)\end{array}$ & $\begin{array}{c}6 \\
\text { (1/16) }\end{array}$ & $\begin{array}{c}94 \\
(61.55)\end{array}$ & $\begin{array}{c}46 \\
(1328)\end{array}$ & $\begin{array}{c}0 \\
(023)\end{array}$ & $\begin{array}{c}0 \\
\text { (023) }\end{array}$ & $\begin{array}{c}0 \\
(029)\end{array}$ & $\begin{array}{c}40 \\
(3075)\end{array}$ & $\begin{array}{c}69 \\
(2638)\end{array}$ & $\begin{array}{c}13 \\
(18)\end{array}$ \\
\hline $\operatorname{sr}(102)$ & $\begin{array}{c}3 \\
\text { (129) }\end{array}$ & $\begin{array}{c}4 \\
(368)\end{array}$ & $\begin{array}{c}0 \\
\text { (018) }\end{array}$ & $\begin{array}{c}0 \\
(028)\end{array}$ & $\begin{array}{c}12 \\
(650)\end{array}$ & $\begin{array}{c}7 \\
\text { (115) }\end{array}$ & $\begin{array}{c}0 \\
\text { (0.13) }\end{array}$ & $\begin{array}{c}0 \\
\text { (0177) }\end{array}$ & $\begin{array}{c}47 \\
(41.177)\end{array}$ & $\begin{array}{c}26 \\
(5 n 9)\end{array}$ & $\begin{array}{c}0 \\
(0.12)\end{array}$ & $\mathrm{sp}(3)$ & & & & & & & & & & & \\
\hline $\operatorname{sim}(47)$ & $\begin{array}{c}0 \\
\text { (on1) }\end{array}$ & $\begin{array}{c}3 \\
(131)\end{array}$ & $\begin{array}{c}0 \\
\text { (04) }\end{array}$ & $\begin{array}{c}0 \\
\text { (018) }\end{array}$ & $\begin{array}{c}0 \\
(022)\end{array}$ & $\begin{array}{c}11 \\
(19)\end{array}$ & $\begin{array}{c}0 \\
\text { (04) }\end{array}$ & $\begin{array}{c}0 \\
(04)\end{array}$ & $\begin{array}{c}14 \\
(642)\end{array}$ & $\begin{array}{c}23 \\
(3 / 3)\end{array}$ & $\begin{array}{c}0 \\
(05)\end{array}$ & $\operatorname{srs} \operatorname{sim}(0)$ & & & & & & & & & & & \\
\hline CA3 total $(18)$ & $\begin{array}{c}25 \\
(14)\end{array}$ & $\begin{array}{c}31 \\
(413)\end{array}$ & $\begin{array}{c}0 \\
\text { (04) }\end{array}$ & \begin{tabular}{|l}
43 \\
(37)
\end{tabular} & $\begin{array}{r}43 \\
(37)\end{array}$ & $\begin{array}{c}0 \\
(03)\end{array}$ & & $\begin{array}{c}0 \\
(04)\end{array}$ & $\begin{array}{r}43 \\
(614)\end{array}$ & $\begin{array}{c}0 \\
\text { (01) }\end{array}$ & & CA3 total $(219)$ & \begin{tabular}{|c}
11 \\
$(761)]$
\end{tabular} & $\begin{array}{c}29 \\
(1448)\end{array}$ & $\begin{array}{r}23 \\
(855)\end{array}$ & $\begin{array}{c}93 \\
(97104)\end{array}$ & $\begin{array}{c}25 \\
\text { (1248) }\end{array}$ & $\begin{array}{c}4 \\
(248)\end{array}$ & $\begin{array}{c}4 \\
\text { (248) }\end{array}$ & $\begin{array}{c}2 \\
(161)\end{array}$ & $\begin{array}{c}41 \\
(460113)\end{array}$ & $\begin{array}{r}84 \\
(3643)\end{array}$ & $\begin{array}{c}0 \\
0 \\
(0199)\end{array}$ \\
\hline so (1) & - & & & - & - & . & & & & & & so (114) & $\begin{array}{c}14 \\
(537)\end{array}$ & $\begin{array}{c}45 \\
\text { (1329) }\end{array}$ & $\begin{array}{c}6 \\
\text { (1156) }\end{array}$ & $\begin{array}{c}90 \\
(4752)\end{array}$ & $\begin{array}{c}14 \\
(429)\end{array}$ & $\begin{array}{c}5 \\
\text { (120) }\end{array}$ & $\begin{array}{c}5 \\
\text { (120) }\end{array}$ & $\begin{array}{c}3 \\
(137)\end{array}$ & $\begin{array}{c}56 \\
(2550)\end{array}$ & $\begin{array}{c}93 \\
(13444)\end{array}$ & $\begin{array}{c}0 \\
(0.14)\end{array}$ \\
\hline $\mathrm{sp} / \mathrm{sl}(1)$ & - & & & - & & & & & & & & spslis(50) & $\begin{array}{c}0 \\
\text { (onn1) }\end{array}$ & $\begin{array}{c}0 \\
\text { (010) }\end{array}$ & $\begin{array}{r}46 \\
\text { (613) }\end{array}$ & $\begin{array}{r}90 \\
(1820)\end{array}$ & $\begin{array}{r}60 \\
6010\end{array}$ & $\begin{array}{c}0 \\
(016)\end{array}$ & $\begin{array}{c}0 \\
\text { (016) }\end{array}$ & $\begin{array}{c}0 \\
(0.14)\end{array}$ & $\begin{array}{c}15 \\
(426)\end{array}$ & $\begin{array}{c}71 \\
(5 \pi)\end{array}$ & $\begin{array}{c}0 \\
(03)\end{array}$ \\
\hline $\operatorname{srs} \operatorname{sim}(16)$ & $\begin{array}{c}25 \\
(14)\end{array}$ & $\begin{array}{c}36 \\
(411)\end{array}$ & $\begin{array}{c}0 \\
\text { (04) }\end{array}$ & $\begin{array}{r}43 \\
(37)\end{array}$ & $\begin{array}{l}40 \\
(25)\end{array}$ & $\begin{array}{c}0 \\
(0.3)\end{array}$ & & $\begin{array}{c}0 \\
(04)\end{array}$ & $\begin{array}{c}50 \\
(612)\end{array}$ & $\begin{array}{c}0 \\
\text { (01) }\end{array}$ & & $\mathrm{st} / \mathrm{s} \operatorname{lm}(55)$ & $\begin{array}{c}20 \\
(210)\end{array}$ & $\begin{array}{c}11 \\
(19)\end{array}$ & $\begin{array}{c}17 \\
\text { (16) }\end{array}$ & $\begin{array}{c}100 \\
(323252)\end{array}$ & $\begin{array}{c}22 \\
(29)\end{array}$ & $\begin{array}{c}8 \\
(1 / 122)\end{array}$ & $\begin{array}{c}9 \\
\text { (111) }\end{array}$ & $\begin{array}{c}0 \\
\text { (용) }\end{array}$ & $\begin{array}{c}38 \\
(1437)\end{array}$ & $\begin{array}{c}82 \\
(1822)\end{array}$ & $\begin{array}{c}0 \\
(02)\end{array}$ \\
\hline DG hilus (11) & $\begin{array}{c}0 \\
(022)\end{array}$ & $\begin{array}{c}0 \\
(05)\end{array}$ & $\begin{array}{c}0 \\
\text { (an) }\end{array}$ & $\begin{array}{r}75 \\
\text { (34) }\end{array}$ & $\begin{array}{r}80 \\
(45)\end{array}$ & $\begin{array}{c}0 \\
\text { (on) }\end{array}$ & $\begin{array}{c}0 \\
(02)\end{array}$ & $\begin{array}{c}0 \\
(02)\end{array}$ & $\begin{array}{c}11 \\
(19)\end{array}$ & $\begin{array}{c}0 \\
(03)\end{array}$ & & DG hilus $(60)$ & $\begin{array}{c}0 \\
(016)\end{array}$ & (on2) & $\begin{array}{c}21 \\
(344)\end{array}$ & $\begin{array}{c}100 \\
(31 ; 1)\end{array}$ & $\begin{array}{c}92 \\
(11 / 2)\end{array}$ & $\begin{array}{c}0 \\
\text { (0in2) }\end{array}$ & $\begin{array}{c}0 \\
\text { (012) }\end{array}$ & $\begin{array}{c}0 \\
\text { (용 }\end{array}$ & $\begin{array}{c}12 \\
(433)\end{array}$ & $\begin{array}{c}15 \\
(213)\end{array}$ & $\begin{array}{c}0 \\
(07)\end{array}$ \\
\hline
\end{tabular}

Values indicate the percentages of retrogradely labeled neurons positive for a given molecule over the number of neurons tested for that molecule (cell numbers in parentheses). Each cell was tested for two to six molecules; therefore, it contributes to several columns. Retrogradely labeled nonpyramidal neurons in str. pyramidale are not shown individually because of the difficulty of differentiating them from labeled pyramidal cells. The few that we identified, two hippocampo-subicular neurons in CA1 and one in CA3 str. pyramidale and three hippocampo-septal neurons in CA1 and eight in CA3 str. pyramidale, are included in the totals. The color code indicates the extent of the expression according to the key at lower right.

lobe with distinct spike-timing during network oscillation. At least four types of GABAergic neurons in the hippocampal CA1 area have interregional synaptic projections in addition to their local circuit axons (Fig. 7): (1) double-projection cells, which project to the medial septum and the retrohippocampal areas, and overlap with the previously described hippocampo-septal neurons of str. oriens (Alonso and Kohler, 1982; Schwerdtfeger and Buhl, 1986; Toth and Freund, 1992; Jinno and Kosaka, 2002; Gulyas et al., 2003); (2) oriens-retrohippocampal neurons that do not project to the septum; (3) trilaminar cells in stratum oriens that project to the subiculum (Ferraguti et al., 2005); and (4) radiatum-retrohippocampal neurons with cell bodies mainly at the border of str. lacunosum-moleculare that innervate the molecular layer of subiculum, presubiculum, retrosplenial cortex, and indusium griseum. The diameter of the long-range myelinated axon collaterals of nonpyramidal neurons is larger than that of the pyramidal cells interconnecting the same regions, predicting fast feedforward GABAergic influence.

The diversity of GABAergic long-range projections is further indicated by within-group differences in molecular profiles demonstrated here and by previous reports. Interneurons have been reported with axonal arborization not respecting hippocampal areal boundaries, including the so-called CA1 backprojection cell innervating the CA3 area and the dentate gyrus (Sik et al., 1994), the perforant path associated cells innervating CA1 and subicular pyramidal cells and dentate granule cells (Ceranik et al., 1997; Vida et al., 1998; Klausberger et al., 2005), and the hippocamposubicular cells in the mouse (Losonczy et al., 2002). Overall, at least seven types of GABAergic projection neurons exist in the CA1 area.

Interregional GABAergic neurons have been described also in the adult isocortex (Gonchar et al., 1995; Fabri and Manzoni, 1996; Jinno and Kosaka, 2004; Tomioka et al., 2005; Apergis-
Schoute et al., 2007). In the isocortex, there are extensive and highly specific interlaminar GABAergic connections between cortical layers by many types of interneuron (Ramon y Cajal, 1911; Somogyi et al., 1981; Kisvarday et al., 1987) ensuring coordination of intrinsic processing with columnar outputs. The interareal GABAergic connections in the temporal lobe may partly fulfill the roles of interlaminar GABAergic connections in the isocortex. In the hippocampal formation, the CA1-3 areas and the subiculum may be analogous with the supragranular layers and layers $5 / 6$ of the isocortex, respectively (Ishizuka, 2001). The temporal coordination of the intrinsic activity in CA1-3 with the activation of outputs from the subiculum and presubiculum may be enhanced by direct, fast-conducting GABAergic coordination in addition to glutamatergic connections. The projecting GABAergic cells ensure coordination along the whole septohippocampal axis and extend it to functionally coupled areas of the temporal episodic memory system such as the retrosplenial cortex.

\section{Interregional temporal coordination by long-range GABAergic interneurons}

Explaining the observed long-range synchronization of cortical activity remains a major challenge. The model by Traub suggests that disparate local oscillators are linked together by the projection axons of principal cells, the phase-locked discharges of which impose a pacing effect on the target oscillator at gamma and $\beta$ frequency via local interneurons (Traub et al., 1996; Bibbig et al., 2002). In an alternative model, local interneurons are supplemented by a set of long-range GABAergic neurons, which can provide precise interregional timing for the principal cells (Buzsaki and Chrobak, 1995). Our observations provide a circuit basis for the latter conjecture and suggest that the two mechanisms complement each other in the temporal lobe, as also shown 
in the projection from the perirhinal to the entorhinal cortex (Apergis-Schoute et al., 2007). First, the axon diameter of longrange nonpyramidal neurons was larger and their myelin thicker than that of the pyramidal neurons connecting the same regions, suggesting that the spread of inhibition across regions can be faster than excitation. Monosynaptic IPSPs could reset ongoing intrinsic oscillations in the target cells (Pike et al., 2000), priming them for the effective encoding of temporally correlated EPSPs. Such a scenario would lead to zero phase lag in synchronized oscillations between cortical areas in the temporal lobe, as observed in the sensory cortices (Roelfsema et al., 1997). The relatively small number of distantly originating GABAergic synapses on pyramidal cells might still become significant near threshold in reverberating oscillating networks with nonlinear dynamics. Second, longrange axons of nonpyramidal neurons of the $\mathrm{CA} 1$ region project to the medial septum, CA3, dentate gyrus, indusium griseum, and retrosplenial cortex (i.e., regions not innervated by the CA1 pyramidal cells). The GABAergic projection to the retrosplenial cortex may be particularly extensive as revealed independently from our study by retrograde labeling (Miyashita and Rockland, 2007). These findings show that long-range interneurons are involved in specialized functions not delivered by the principal cells.

The firing pattern of double-projection cells and their simultaneous innervation of three interconnected areas is a prominent example of the spatiotemporal requirements of long-range coordination. During ripple oscillations (O'Keefe, 1976), doubleprojection cells fire with the highest discharge rate releasing GABA in the medial septum to both GABAergic and cholinergic neurons (Toth et al., 1993). This activity might lead to a suppression of the majority of cells (Dragoi et al., 1999) and disrupt the generation of theta oscillations. Their local axons in the CA1 area innervate pyramidal cell dendrites, as shown here (but see Gulyas et al., 2003), and cooperatively release GABA with the bistratified cells, which fire at high frequency (Klausberger et al., 2004) during the ascending phase of the extracellular ripple cycle and innervate the same pyramidal cell domains acting on $\mathrm{GABA}_{\mathrm{A}}$ receptors (Pawelzik et al., 1999). Together, they temporally structure the excitation of the CA3 input in CA1 pyramidal dendrites at ripple frequency. The third axonal arbor of doubleprojection cells in the subiculum, together with other oriensretrohippocampal GABAergic cells, also innervates dendrites of pyramidal cells and contributes to communicating the temporal structure of ripple oscillations to the subiculum, which oscillates coherently with the CA1 area (Chrobak and Buzsaki, 1996). Because rhythmic IPSCs may precede EPSCs in subicular pyramidal cells, they may reset the excitability and oscillatory phase of their dendritic targets just before the arrival of glutamatergic input. Unlike double projection cells, radiatum projection neurons do not change their activity during ripples and are unlikely to contribute to coordinating this network state, indicating a different
Hippocampus (CA1 area)

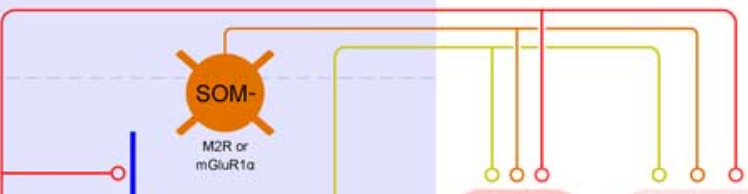

Pre/Parasubiculum

Retrosplenial

cortex
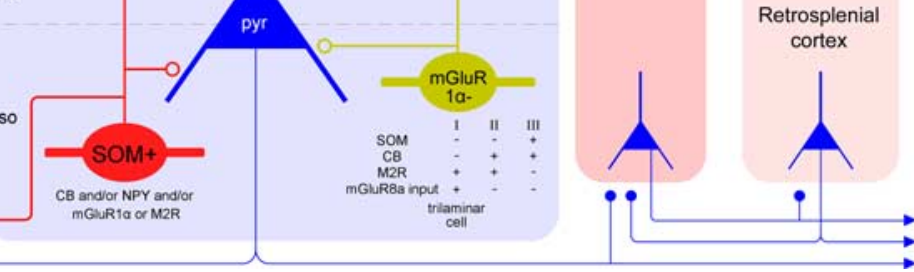

Figure 7. Diagram showing the novel subsets of CA1 hippocampal GABAergic neurons projecting to the septal and/or retrohippocampal areas. The in vivo single-cell labeling and retrograde tracer experiments suggest three main types of hippocampal ABAergic projection neuron. The first major population (red) is located in str. oriens, projects to both the retrohippocampal and ( The second population (green) is less common in str. oriens, projects exclusively

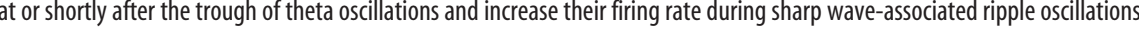
ements of an individual neuron can be other interneurons. The third population (brown), found in the str. radiatum and -moleculare; so, str. oriens; sp, str. pyramidale; sr, str. radiatum

function for these cells. Importantly, other interneurons that innervate the distal apical dendrites of pyramidal cells, including O-LM and perforant path-associated cells (Klausberger et al., 2003, 2005) also do not change their firing during ripple oscillations. Therefore, we suggest that as a general rule, there is no increase in GABA release to the most distal dendrites of pyramidal cells in the different areas during ripple oscillations.

Long-range double-projection neurons, oriens-retrohippocampal neurons, trilaminar cells, and local bistratified cells fire at the trough of pyramidal layer extracellular theta oscillations, when assemblies of CA1 pyramidal cells are most active (Buzsaki et al., 1983; Fox and Ranck, 1986). The time-locked maximal activity of GABAergic and glutamatergic cells serve to provide improved time resolution of spiking by decreased temporal windows within which principal cells can discharge. Indeed, we found that double-projection cells fire rhythmically just after pyramidal cells (Csicsvari et al., 2003) during gamma oscillations, which occur nested with the slower theta waves. Because bistratified cell firing is also strongly phase-locked to the ascending gamma phase (Tukker et al., 2007), double-projection and bistratified cells cooperatively phase pyramidal cell dendrites at gamma frequencies during theta oscillations. In contrast to the locally terminating bistratified cells, double-projection neurons also provide this gamma/theta modulation to the subset of concurrently active septal (Dragoi et al., 1999) and subicular pyramidal cells.

During theta oscillations, which can co-occur in hippocampal and isocortical areas (Jones and Wilson, 2005), doubleprojection neurons fire with relatively low discharge frequency, whereas the firing of the radiatum-retrohippocampal cells 
strongly increases. In firing preferentially on the descending theta phase, radiatum-retrohippocampal neurons are different from the local dendrite-innervating O-LM, CCK-expressing, and bistratified cells (Klausberger et al., 2003, 2004, 2005), but the sparse local axon arborization probably makes relatively little contribution to IPSCs in the hippocampus. Resulting from their dendritic locations, CA3, entorhinal, and/or thalamic glutamatergic inputs may activate these cells and therefore they could communicate the timing of these glutamatergic inputs via their widespread GABAergic projections to other areas of the temporal lobe, including the subiculum, retrosplenial cortex, and indusium griseum.

In conclusion, the spike timing of GABAergic projection neurons is linked to network oscillations, and these cells provide monosynaptic GABAergic innervation to functionally coupled brain regions, supplementing the well-known glutamatergic interregional pyramidal cell connections and the shared thalamic, basal forebrain, and brainstem inputs. The evolutionary differentiation and ontogenetic retention of GABAergic projection cell types in the temporal lobe may result from the need to coordinate precisely the multiple activity patterns of widespread cortical cell assemblies in different brain states and among multiple functionally related brain areas.

\section{References}

Acsady L, Gorcs TJ, Freund TF (1996) Different populations of vasoactive intestinal polypeptide-immunoreactive interneurons are specialized to control pyramidal cells or interneurons in the hippocampus. Neuroscience 73:317-334.

Alonso A, Kohler C (1982) Evidence for separate projections of hippocampal pyramidal and non-pyramidal neurons to different parts of the septum in the rat brain. Neurosci Lett 31:209-214.

Amaral DG, Witter MP (1989) The three-dimensional organization of the hippocampal formation: a review of anatomical data. Neuroscience 31:571-591.

Apergis-Schoute J, Pinto A, Pare D (2007) Muscarinic control of long-range GABAergic inhibition within the rhinal cortices. J Neurosci 27:4061-4071.

Bibbig A, Traub RD, Whittington MA (2002) Long-range synchronization of $\gamma$ and $\beta$ oscillations and the plasticity of excitatory and inhibitory synapses: a network model. J Neurophysiol 88:1634-1654.

Buzsaki G (1984) Feed-forward inhibition in the hippocampal formation. Prog Neurobiol 22:131-153.

Buzsaki G, Chrobak JJ (1995) Temporal structure in spatially organized neuronal ensembles: a role for interneuronal networks. Cur Opin Neurobiol 5:504-510.

Buzsaki G, Leung L-W, Vanderwolf CH (1983) Cellular bases of hippocampal EEG in the behaving rat. Brain Res Brain Res Rev 6:139-171.

Caviness Jr VS, Sidman RL (1973) Retrohippocampal, hippocampal and related structures of the forebrain in the reeler mutant mouse. J Comp Neurol 147:235-254.

Ceranik K, Bender R, Geiger JRP, Monyer H, Jonas P, Frotscher M, Lubke J (1997) A novel type of GABAergic interneuron connecting the input and the output regions of the hippocampus. J Neurosci 17:5380-5394.

Chrobak JJ, Buzsaki G (1996) High-frequency oscillations in the output networks of the hippocampal-entorhinal axis of the freely behaving rat. J Neurosci 16:3056-3066.

Csicsvari J, Jamieson B, Wise KD, Buzsaki G (2003) Mechanisms of gamma oscillations in the hippocampus of the behaving rat. Neuron 37:311-322.

Dragoi G, Carpi D, Recce M, Csicsvari J, Buzsaki G (1999) Interactions between hippocampus and medial septum during sharp waves and theta oscillation in the behaving rat. J Neurosci 19:6191-6199.

Fabri M, Manzoni T (1996) Glutamate decarboxylase immunoreactivity in corticocortical projecting neurons of rat somatic sensory cortex. Neuroscience 72:435-448.

Fabri M, Manzoni T (2004) Glutamic acid decarboxylase immunoreactivity in callosal projecting neurons of cat and rat somatic sensory areas. Neuroscience 123:557-566.
Felleman DJ, Van Essen DC (1991) Distributed hierarchical processing in the primate cerebral cortex. Cereb Cortex 1:1-47.

Ferraguti F, Klausberger T, Cobden P, Baude A, Roberts JDB, Szucs P, Kinoshita A, Shigemoto R, Somogyi P, Dalezios Y (2005) Metabotropic glutamate receptor 8-expressing nerve terminals target subsets of GABAergic neurons in the hippocampus. J Neurosci 25:10520-10536.

Fox SE, Ranck JB (1986) Hippocampal theta rhythm and the firing of neurons in walking and urethane anesthetized rats. Exp Brain Res 62:495-508.

Gonchar YA, Johnson PB, Weinberg RJ (1995) GABA-immunopositive neurons in rat neocortex with contralateral projections to S-I. Brain Res 697:27-34.

Gulyas AI, Hajos N, Freund TF (1996) Interneurons containing calretinin are specialized to control other interneurons in the rat hippocampus. J Neurosci 16:3397-3411.

Gulyas AL, Hajos N, Katona I, Freund TF (2003) Interneurons are the local targets of hippocampal inhibitory cells which project to the medial septum. Eur J Neurosci 17:1861-1872.

Henze DA, Wittner L, Buzsaki G (2002) Single granule cells reliably discharge targets in the hippocampal CA3 network in vivo. Nat Neurosci 5:790-795.

Ishizuka N (2001) Laminar organization of the pyramidal cell layer of the subiculum in the rat. J Comp Neurol 435:89-110.

Jinno S, Kosaka T (2002) Immunocytochemical characterization of hippocamposeptal projecting GABAergic nonprincipal neurons in the mouse brain: a retrograde labeling study. Brain Res 945:219-231.

Jinno S, Kosaka T (2004) Parvalbumin is expressed in glutamatergic and GABAergic corticostriatal pathway in mice. J Comp Neurol 477:188-201.

Jones MW, Wilson MA (2005) Phase precession of medial prefrontal cortical activity relative to the hippocampal theta rhythm. Hippocampus 15:867-873.

Kisvarday ZF, Martin KAC, Friedlander MJ, Somogyi P (1987) Evidence for interlaminar inhibitory circuits in the striate cortex of the cat. J Comp Neurol 260:1-19.

Klausberger T, Magill PJ, Marton L, Roberts JDB, Cobden PM, Buzsáki G, Somogyi P (2003) Brain state- and cell type-specific firing of hippocampal interneurons in vivo. Nature 421:844-848.

Klausberger T, Marton LF, Baude A, Roberts JDB, Magill P, Somogyi P (2004) Spike timing of dendrite-targeting bistratified cells during hippocampal network oscillations in vivo. Nat Neurosci 7:41-47.

Klausberger T, Marton LF, O’Neill J, Huck JHJ, Dalezios Y, Fuentealba P, Suen WY, Papp E, Kaneko T, Watanabe M, Csicsvari J, Somogyi P (2005) Complementary roles of cholecystokinin- and parvalbumin- expressing GABAergic neurons in hippocampal network oscillations. J Neurosci 25:9782-9793.

Leranth C, Frotscher M (1987) Cholinergic innervation of hippocampal GAD- and somatostatin-immunoreactive commissural neurons. J Comp Neurol 261:33-47.

Losonczy A, Zhang L, Shigemoto R, Somogyi P, Nusser Z (2002) Cell type dependence and variability in the short-term plasticity of EPSCs in identified mouse hippocampal interneurones. J Physiol (Lond) 542:193-210.

Miles R, Toth K, Gulyas AI, Hajos N, Freund TF (1996) Differences between somatic and dendritic inhibition in the hippocampus. Neuron 16:815-823.

Miyashita T, Rockland KS (2007) GABAergic projections from the hippocampus to the retrosplenial cortex in the rat. Eur J Neurosci, in press.

O'Keefe J (1976) Place units in the hippocampus of the freely moving rat. Exp Neurol 51:78-109.

Pawelzik H, Bannister AP, Deuchars J, Ilia M, Thomson AM (1999) Modulation of bistratified cell IPSPs and basket cell IPSPs by pentobarbitone sodium, diazepam and $\mathrm{Zn}^{2+}$ : dual recordings in slices of adult rat hippocampus. Eur J Neurosci 11:3552-3564.

Pike FG, Goddard RS, Suckling JM, Ganter P, Kasthuri N, Paulsen O (2000) Distinct frequency preferences of different types of rat hippocampal neurones in response to oscillatory input currents. J Physiol (Lond) 529:205-213.

Ramon y Cajal S (1911) Histologie du systeme nerveux de l'homme et des vertebres. Paris: Maloine.

Ribak CE, Seress L, Peterson GM, Seroogy KB, Fallon JH, Schmued LC (1986) A GABAergic inhibitory component within the hippocampal commissural pathway. J Neurosci 6:3492-3498.

Rockland KS (1997) Elements of cortical architecture hierarchy revisited. 
In: Cerebral cortex (Rockland KS, Kaas J, Peters A, eds), pp 243-293. New York: Plenum.

Roelfsema PR, Engel AK, Konig P, Singer W (1997) Visuomotor integration is associated with zero time-lag synchronization among cortical areas. Nature 385:157-161.

Schwerdtfeger WK, Buhl E (1986) Various types of non-pyramidal hippocampal neurons project to the septem and contralateral hippocampus. Brain Res 386:146-154.

Sik A, Ylinen A, Penttonen M, Buzsaki G (1994) Inhibitory CA1-CA3-hilar region feedback in the hippocampus. Science 265:1722-1724.

Sik A, Penttonen M, Ylinen A, Buzsaki G (1995) Hippocampal CA1 interneurons: an in vivo intracellular labeling study. J Neurosci 15:6651-6665.

Somogyi P, Takagi H (1982) A note on the use of picric acidparaformaldehyde-glutaraldehyde fixative for correlated light and electron microscopic immunocytochemistry. Neuroscience 7:1779-1783.

Somogyi P, Cowey A, Halasz N, Freund TF (1981) Vertical organization of neurons accumulating ${ }^{3} \mathrm{H}-\mathrm{GABA}$ in the visual cortex of the Rhesus monkey. Nature 294:761-763.

Somogyi P, Tamas G, Lujan R, Buhl EH (1998) Salient features of synaptic organisation in the cerebral cortex. Brain Res Brain Res Rev 26:113-135.

Tomioka R, Okamoto K, Furuta T, Fujiyama F, Iwasato T, Yanagawa Y, Obata K, Kaneko T, Tamamaki N (2005) Demonstration of long-range
GABAergic connections distributed throughout the mouse neocortex. Eur J Neurosci 21:1587-1600.

Toth K, Freund TF (1992) Calbindin D28k-containing nonpyramidal cells in the rat hippocampus: their immunoreactivity for GABA and projection to the medial septum. Neuroscience 49:793-805.

Toth K, Borhegyi Z, Freund TF (1993) Postsynaptic targets of GABAergic hippocampal neurons in the medial septum diagonal band of Broca complex. J Neurosci 13:3712-3724.

Traub RD, Whittington MA, Stanford IM, Jefferys JGR (1996) A mechanism for generation of long-range synchronous fast oscillations in the cortex. Nature 383:621-624.

Tukker JJ, Fuentealba P, Hartwich K, Somogyi P, Klausberger T (2007) Cell type-specific tuning of hippocampal interneuron firing during gamma oscillations in vivo. J Neurosci, in press.

Uhlhaas PJ, Singer W (2006) Neural synchrony in brain disorders: relevance for cognitive dysfunctions and pathophysiology. Neuron 52:155-168.

van Haeften T, Wouterlood FG, Jorritsma-Byham B, Witter MP (1997) GABAergic presubicular projections to the medial entorhinal cortex of the rat. J Neurosci 17:862-874.

Vida I, Halasy K, Szinyei C, Somogyi P, Buhl EH (1998) Unitary IPSPs evoked by interneurons at the stratum radiatum-stratum lacunosummoleculare border in the CAl area of the rat hippocampus in vitro. J Physiol (Lond) 506:755-773. 